\title{
Drought Strategy Tolerance of Four Barley Cultivars and Combined Effect with Salicylic Acid Application
}

\author{
Hamdia M. Abd El-Samad, Mohamed Abdo Kheder Shaddad, Marwa Mohamed Ragaey \\ Botany and Microbiology Department, Faculty of Science, Minia University, Minya, Egypt \\ Email: hamdia10@yahoo.com
}

How to cite this paper: El-Samad, H.M.A., Shaddad, M.A.K. and Ragaey, M.M. (2019) Drought Strategy Tolerance of Four Barley Cultivars and Combined Effect with Salicylic Acid Application. American Journal of Plant Sciences, 10, 512-535.

https://doi.org/10.4236/ajps.2019.104037

Received: September 18, 2018

Accepted: April 14, 2019

Published: April 17, 2019

Copyright ( 2019 by author(s) and Scientific Research Publishing Inc. This work is licensed under the Creative Commons Attribution International License (CC BY 4.0).

http://creativecommons.org/licenses/by/4.0/

\begin{abstract}
This investigation was conducting to explain that four barley genotypes varied in their drought tolerance according to their genotype and their tested organs. It can be recorded that growth parameters (fresh, dry matter and length, water content, leaf area and pigment contents) were decreased as decreasing M. C. in the soil. This indicated that Giza 123 was the superior in its drought tolerance and Giza 129 was the interior and both cv. Giza 2000 and cv. Giza 124 were the intermediated between them. This concomitant with increase in soluble sugar and soluble protein content of both organs in Giza 123 and shoot $\mathrm{Ca}^{++}$, this related with lower value of OP other than genotypes, in Giza 2000 this was related with a huge accumulation in soluble protein of shoot and root, shoot amino acids and root proline reach 3-folds than control plants as decreasing M. C. Whereas drought stress increased soluble protein only in Giza 124 while in Giza 129 decreasing M. C. increased soluble protein, amino acids and proline contents in shoot and root and shoot $\mathrm{Ca}^{++}$. The values of OP increased as decreasing M. C. in four barley cultivars concomitant with their drought tolerance. Also, SA application was markedly enhanced the production of growth parameters in shoot and root with varied degree according to each tested barley genotypes. SA application was significantly increased OP in shoot, root and spike of barley pants. Spraying vegetative parts with $0.5 \mathrm{mM} \mathrm{SA}$ was markedly increased the soluble sugar, soluble protein and amino acids in shoot, root and spike of four barley cultivars. On the other side, SA application lowered the accumulation of proline in shoot and root of barley genotypes. SA treatment induced no significant change in $\mathrm{K}^{+}$, $\mathrm{Ca}^{++}$, and $\mathrm{Mg}^{++}$in shoot, root and spike of Giza 123, it significantly increased $\mathrm{K}^{+}, \mathrm{Ca}^{++}$, and $\mathrm{Mg}^{++}$in shoot and root of Giza 2000. SA application enhanced accumulation of $\mathrm{K}^{+}, \mathrm{Ca}^{++}$in shoot and root of Giza 124 and $\mathrm{K}^{+}, \mathrm{Ca}^{++}$and $\mathrm{Mg}^{++}$in three organs of Giza 129.
\end{abstract}




\section{Keywords}

Drought, Barley Cultivar, Salicylic Acid

\section{Introduction}

Recent scientific advances make exploration of genotypic selection to drought stress was feasible and could result in large gains in productivity. Drought stress is one of the most adverse factors on plant growth and productivity, it induced morphological, physiological and biochemical changes, reduced $\mathrm{CO}_{2}$ assimilation, leaf area, pigment content, stem expansion, root proliferations disturbs water use efficiency. The role of chemical constituent's accumulation in drought plants has been researched to understand plant tolerance to dehydration. Also drought increase active oxygen ROS species generation and can be controlled by increased antioxidant enzmes [1] [2] [3] [4]. SA is involved in the regulation of important plant physiological processes such as photosynthesis, nitrogen metabolism, proline (Pro) metabolism, production of glycinebetaine (GB), antioxidant defense system, and plant-water relations under stress conditions and thereby provides protection in plants against abiotic stresses [5]. A common effect of abiotic stresses, including drought, is oxidative damage due to a loss of balance between the production and elimination of reactive oxygen species (ROS) [6]. If not effectively and rapidly removed from plants, excessive ROS may damage a wide range of cellular macromolecules such as lipid, protein and DNA and ultimately cause cell damage. Salicylic acid (SA) is a naturally occurring phenolic compound. SA plays an important role in the regulation of plant growth, development, ripening, and defense [7] [8]. In general, low concentrations of SA may enhance the antioxidant capacity in plants, but high concentrations of SA may cause cell death or susceptibility to abiotic stresses [8] [9]. In addition to being an important component of biotic stress tolerance mechanism, SA also regulates various aspects of plant responses to abiotic stresses through extensive signaling cross-talk with other growth hormones [5] [10] [11] [12]. Many studies have so far been conducting to identify its role in abiotic stress tolerance in different crops. Results of these studies suggest that exogenously applied SA can induce drought resistance in wheat [13] [14] [15]. The present work was to study the mechanisms of drought tolerance strategy of four barley cultivars and their response to the exogenous addition of salicylic acids.

\section{Materials and Methods}

\subsection{Experimental Sites and Drought Stress Treatments}

Barley grain cultivars were obtained from the breeding program of seeds station, Beni-Suef, Egypt. Barley grains were surface sterilized by immersion in a mixture of ethanol $96 \%$ and $\mathrm{H}_{2} \mathrm{O}_{2}$ (1:1) for 3 minutes, followed by several washings with sterile distilled water, seeds were grown in $1 \mathrm{~kg}$ pots in Botany and Microbiology 
Department garden. Barley plant was considered as one of the most important crop plants in Egypt because of its contribution as nutrient foods for people. Barley is a major cereal grain commonly found in bread, beverages and various cuisines of every culture. It remains one of the most widely consumed grains, globally, source of dietary. Fiber, vitamins and minerals are not found in refined and enriched grains. Five seeds were sown in each pot and soil was brought to field capacity. The seedlings were left to grow under the desired soil moisture content levels (90\%, 70\%, 50\% and 30\%). Soil moisture content was measured by calculate the soil field capacity, this consider as $100 \%$ moisture content and so could be determine the other lower soil moisture content. The clay soil comprise four components minerals and soil organic matter make up the solid fraction, whereas air and water comprise the pore space fraction. A typical agricultural soil is usually around $50 \%$ solid particles and $50 \%$ pores (Adapted from Brady and Weil, 2002) [16]. Soil particle of clay is $<0.002$ invisible to naked eye. Considerations of working in controlled environments were followed by Tibbitts \& Langhans [17].

\subsection{Drought Stress and Treatments with Salicylic Acid}

The previous treatments were repeated for treatment with spraying vegetative parts with $0.5 \mathrm{mM} \mathrm{SA}$ as second groups. Three replicate was made for each treatment and plants were grown in natural conditions for crop yield production at 120-days.

\subsection{Laboratory Analysis for Metabolities}

At the end of the experimental period (120 days) plant height, dry matter yield of the different organs (shoot, root and spike) were determined. Plant height was determined by direct measurement from soil surface to the tip of the flag leaf. Determination of the dry matter involved harvesting and careful separation of fresh organs. Fresh organs were then dried in an oven at $80^{\circ} \mathrm{C}$. Successive weighing was carried out until a constant dry weight was recorded. The plants were uprooted, roots carefully separated from the soil, washed and the length of roots were measured. From determining the shoot and root weight, was calculated. Leaf area was determined by measuring leaf length and maximum width and applying the formula; Leaf area $=\mathrm{k}$ (leaf length ${ }^{*}$ leaf maximum width) $\mathrm{Cm}^{2}$ plant $^{-1}$. This formula provided a simple way for determination of leaf area particularly in the field where large leaves had to be measured. The coefficient $\mathrm{k}$ was calculated and assigned different values for different grasses [18] [19], and recently reviewed and given a value of 0.75 for maize [20]. Dry matter was determined after drying plants in an aerated oven at $70^{\circ} \mathrm{C}$ to constant mass. Pigment content was measured by Metzner [21]. Saccharides were determined by the anthrone-sulfuric acids method [22]. Soluble protein was measured according to Lowry et al. (1951) [23]. Amino acids and proline were measured by Moore and Stein (1948) and Bates et al. (1973) [24] [25]. Sodium and potassium were de- 
termined by flam photometric method [26], and calcium and magnesium by the versene titration method [27].

\subsection{Statistical Analysis}

The experimental data were subjected to the one way analysis of variances (ANOVA test) using the SPSS version 11.0 to quantify and evaluate the source of variation and the means were separated by the least significant differences, L. S. D. at P level of $0.05 \%$ [28]. Experimental data were subjected to one way analysis of variance and the means were separated by the least significant differences, $\mathrm{L}$. S. D. [28]. Correlation coefficients were calculated using statgraphics 5.0 software.

\section{Results}

\subsection{Growth Parameters}

In cv. Giza 123 decreasing moisture content induced three position the firstly was more or less have the same value of control $100 \%$ in shoot fresh matter, secondly a marked increase in shoot dry matter was detected up to $50 \% \mathrm{M}$. C., thirdly in root there is a slight decreasing effect in fresh and dry matter up to $70 \%$ (Table 1(a)). After that level, a significant reduction in fresh and dry matter was induced reach a low level at $30 \%$ M. C., the percent of reduction was $84 \%$ and $72.4 \%$. Length of both organs showed a decreasing effect reach a $20 \%$ at $30 \%$ M. C. compared with control plants (Table 1(a)). Fresh and dry matter of shoot and root of Giza 2000 generally become more or less unchanged up to $70 \%$, after that a marked reduction was recorded (Table $1(\mathrm{~b})$ ). The percent of reduction at $30 \%$ M. C. was $69.3 \%, 81.7 \%, 70.5 \%, 67.2 \%$ in fresh and dry matter of shoot and root respectively. Length in both organs was decreased with decreasing moisture content. The percent of reduction was $58.8 \%$ and $75 \%$ in shoot and root compared with control plants (Table 1(b)). A lowering effect was recorded with decreasing moisture content in fresh and dry matter of shoot, root and length of cv. Giza 124, this effect was more obvious in root than in shoot (Table 1(c)). The percent of reduction in fresh, dry matter and length at $30 \%$ M. C. was $63.9 \%, 63.4 \%, 43.7 \%, 66.6 \%, 65.4 \%$ and $72 \%$. Also decreasing soil moisture content induced a significant reduction in fresh, dry matter and length of Giza 129 from $70 \%$ to $30 \%$ M. C. The percent of reduction was $53.2 \%, 51.4 \%, 39 \%, 34.7 \%$, $51.9 \%$ and $48.4 \%$ in fresh, dry and length of shoot and root at 30\% M. C. (Table 1(d)). Leaf area smoothly decreased at all M. C. levels in cv. Giza 123 moreover a marked reduction was recorded at 50\% and 30\% in both Giza 2000 and Giza 124, however a significant reduction was recorded in cv. Giza 129. The percent of reduction at $30 \%$ M. C. was $81.8 \%, 60.7 \%, 54.9 \%, 53.3 \%$ as compared with control plants (Figure 1). Chlorophyll a, b and carotenoids were significantly decreased as decreasing drought stress in four barley genotypes compared with reference control plants (Figure 2(a) \& Figure 2(b)). The percent of reduction in Chl. a, b and c at 30\% M. C. level was $80.3 \%, 98.9 \%, 67.4 \%$, in Giza 132 plant, 
Table 1. The response of Giza 123 (a), Giza 2000 (b), Giza 124 (c) and Giza 129 (d) barley genotypes to drought stress and interactive with SA treatments on fresh, dry matter $\left(\mathrm{g} \mathrm{plant}^{-1}\right)$ and length $(\mathrm{Cm})$ of shoot, root and spike at the final fruiting stage.

(a)

\begin{tabular}{|c|c|c|c|c|c|c|c|c|c|c|c|c|c|c|c|c|}
\hline \multirow{2}{*}{$\begin{array}{l}\text { Treat. } \\
\text { M. C. }\end{array}$} & \multicolumn{4}{|c|}{ Shoot } & \multicolumn{4}{|c|}{ Root } & \multicolumn{4}{|c|}{ Length } & \multicolumn{4}{|c|}{ Spike } \\
\hline & M. C. & $\%$ & D. m. & $\%$ & F. m. & $\%$ & D. $\mathrm{m}$. & $\%$ & Sh. & $\%$ & Ro. & $\%$ & D. $\mathrm{m}$. & $\%$ & Length & $\%$ \\
\hline $90 \%$ & 7.7 & 100 & 2.8 & 100 & 4.2 & 100 & 0.83 & 100 & 90 & 100 & 3 & 100 & 2.2 & 100 & 17 & 100 \\
\hline $70 \%$ & 8.0 & 100 & 3.6 & 130 & 3.9 & 93.3 & 0.74 & 89 & $85^{\star *}$ & 94 & 27 & 90 & 1.9 & 89.3 & 17.5 & 102.9 \\
\hline $50 \%$ & 7.5 & 104 & 3.1 & 114 & 3.7 & 87.8 & 0.67 & 80.4 & $75.9^{\star *}$ & 84 & 24 & 983 & 1.7 & 75.6 & $15^{\star *}$ & 88.2 \\
\hline $30 \%$ & 7.4 & 96.9 & 2.6 & 96 & 3.5 & 84 & 0.60 & 72.4 & 72.3 & 80 & 24 & 80 & 1.1 & 52.0 & $13.5^{\star *}$ & 79.4 \\
\hline $90 \%+S A$ & 9.7 & 126 & 4.6 & 166 & $5.2^{* *}$ & 124 & 1.1 & 132.5 & 96.3 & 107 & 33 & 110 & 2.4 & 109.0 & $18.5^{\star *}$ & 108.8 \\
\hline $70 \%+S A$ & 9.4 & 123 & 3.9 & 143 & $6.5^{* \star}$ & 156 & 1.2 & 144.7 & 88.2 & 98 & 30 & 99 & 2.5 & 114.3 & 17.5 & 102.9 \\
\hline $50 \%+\mathrm{SA}$ & 7.4 & 96 & 3.3 & 121 & $5.9^{* *}$ & 1421 & 0.96 & 115.7 & 83.7 & 93 & 292 & 95 & 2.2 & 100 & $19.5^{* *}$ & 115 \\
\hline $30 \%+\mathrm{SA}$ & 7.2 & 93 & 2.7 & 99 & 4.1 & 97.6 & 0.74 & 88.9 & 37.9 & 87 & 26 & 85 & 1.4 & 89.3 & 17.5 & 100.8 \\
\hline L. S. D. $0.05 \%$ & \multicolumn{2}{|c|}{0.05} & \multicolumn{2}{|c|}{0.19} & \multicolumn{2}{|c|}{0.25} & \multicolumn{2}{|c|}{0.09} & \multicolumn{2}{|c|}{0.98} & \multicolumn{2}{|c|}{0.94} & \multicolumn{2}{|c|}{0.16} & \multicolumn{2}{|c|}{0.51} \\
\hline
\end{tabular}

(b)

\begin{tabular}{|c|c|c|c|c|c|c|c|c|c|c|c|c|c|c|c|c|}
\hline \multirow{2}{*}{ M. C. } & \multicolumn{4}{|c|}{ Shoot } & \multicolumn{4}{|c|}{ Root } & \multicolumn{4}{|c|}{ Length } & \multicolumn{4}{|c|}{ Spike } \\
\hline & M. C. & $\%$ & D. m. & $\%$ & F. m. & $\%$ & D. m. & $\%$ & Sh. & $\%$ & Ro. & $\%$ & D. m. & $\%$ & Length & $\%$ \\
\hline $90 \%$ & 4.9 & 100 & 1.3 & 100 & 3.0 & 100 & 2.2 & 100 & 0.86 & 100 & 85 & 100 & 1.8 & 100 & 18 & 100 \\
\hline $70 \%$ & 4.6 & 93.9 & 1.4 & 06.9 & 2.9 & 96.7 & 1.9 & 89.3 & 0.76 & 88.2 & 79 & 92.2 & $1.5^{\star *}$ & 81.2 & 17.5 & 97.2 \\
\hline $50 \%$ & 4.3 & 87.8 & 1.2 & 93.1 & 2.5 & 83.3 & 1.7 & 75.6 & 0.66 & 76.2 & 66 & 77.7 & $1.3^{* *}$ & 70.9 & $17^{* *}$ & 94.4 \\
\hline $30 \%$ & 3.4 & 69.4 & 1.0 & 81.7 & 2.0 & 66.7 & 1.1 & 52.0 & 0.52 & 67.2 & 58 & 68.2 & $0.74^{* *}$ & 41.3 & $11.5^{* *}$ & 63.9 \\
\hline $90 \%+\mathrm{SA}$ & 9.4 & 191 & 2.2 & 171 & 3.3 & 109 & 2.4 & 109 & 0.94 & 109.3 & 94 & 110.6 & $2.1^{* *}$ & 119.1 & $19^{* *}$ & 105.6 \\
\hline $70 \%+S A$ & 6.9 & 140.2 & 2.0 & 155.7 & 3.9 & 129 & 2.5 & 114.3 & 1.1 & 127.6 & 83 & 97.7 & 1.8 & 100 & 18 & 100 \\
\hline $50 \%+\mathrm{SA}$ & 6.7 & 136.4 & 1.7 & 129.8 & 3.8 & 126 & 2.2 & 100 & 1.0 & 124.1 & 59 & 69.4 & $1.5^{* *}$ & 83.1 & $16^{* *}$ & 88.9 \\
\hline $30 \%+\mathrm{SA}$ & 5.0 & 102.4 & 1.2 & 90.1 & 2.4 & 78.7 & 1.4 & 89.3 & 0.85 & 98.9 & 55 & 64.7 & 0.93 & 52.1 & $16^{* *}$ & 88.9 \\
\hline L. S. D. $0.05 \%$ & \multicolumn{2}{|c|}{0.19} & \multicolumn{2}{|c|}{0.158} & \multicolumn{2}{|c|}{0.19} & \multicolumn{2}{|c|}{0.16} & \multicolumn{2}{|c|}{0.1} & \multicolumn{2}{|r|}{1.3} & \multicolumn{2}{|c|}{0.22} & \multicolumn{2}{|c|}{0.13} \\
\hline
\end{tabular}

(c)

\begin{tabular}{|c|c|c|c|c|c|c|c|c|c|c|c|c|c|c|c|c|}
\hline \multirow{2}{*}{ M. C. } & \multicolumn{4}{|c|}{ Shoot } & \multicolumn{4}{|c|}{ Root } & \multicolumn{4}{|c|}{ Length } & \multicolumn{2}{|c|}{ Spike } & \multicolumn{2}{|c|}{ Length } \\
\hline & M. C. & $\%$ & D. $\mathrm{m}$. & $\%$ & F. m. & $\%$ & D. $\mathrm{m}$ & $\%$ & Sh. & $\%$ & Ro. & $\%$ & D. m. & $\%$ & Spike & $\%$ \\
\hline $90 \%$ & 5.3 & 100 & 2.2 & 100 & 4.0 & 100 & 0.77 & 100 & 78 & 100 & 25 & 100 & 1.9 & 100 & 15.5 & 100 \\
\hline $70 \%$ & 5.6 & 104.4 & 1.9 & 98.6 & 3.6 & 78.9 & 0.65 & 85.4 & 75 & 96.1 & 23.5 & 94 & $1.6^{\star *}$ & 84.3 & 15 & 96.8 \\
\hline $50 \%$ & 4.8 & 90.2 & 1.8 & 89.6 & 3.1 & 75.6 & 0.56 & 72.9 & 74 & 94.9 & 23 & 92 & $1.1^{* *}$ & 58.9 & $12^{\star *}$ & 77.4 \\
\hline $30 \%$ & 3.4 & 63.9 & 1.4 & 63.4 & 1.3 & 43.7 & 0.57 & 66.6 & 51 & 65.4 & 17 & 68 & $0.6^{* *}$ & 31.6 & $9.5^{\star *}$ & 61.2 \\
\hline $90 \%+\mathrm{SA}$ & 5.3 & 100 & 2.2 & 100.9 & 4.3 & 105.7 & 0.80 & 104.8 & 81 & 03.9 & 28 & 112 & 1.9 & 100.7 & 16.5 & 106.5 \\
\hline $70 \%+S A$ & 5.8 & 109 & 2.3 & 105.4 & 4.1 & 100.7 & 0.78 & 101.6 & 75 & 96.2 & 29 & 116 & 1.9 & 98.7 & 16.5 & 106.5 \\
\hline $50 \%+\mathrm{SA}$ & 5.7 & 106.6 & 2.3 & 104.1 & 5.2 & 129 & 0.91 & 119.2 & 74 & 94.2 & 25 & 100 & 1.8 & 97.1 & 16.5 & 106.5 \\
\hline $30 \%+\mathrm{SA}$ & 4.8 & 90.8 & 2.0 & 90.9 & 2.9 & 74 & 0.57 & 73.8 & 65 & 83.3 & 23.5 & 94 & $0.923^{* *}$ & 49 & $14.5^{* *}$ & 93.5 \\
\hline L. S. D. $0.05 \%$ & \multicolumn{2}{|c|}{0.17} & \multicolumn{2}{|c|}{0.14} & \multicolumn{2}{|c|}{0.13} & \multicolumn{2}{|c|}{0.02} & \multicolumn{2}{|c|}{1.1} & \multicolumn{2}{|c|}{0.73} & \multicolumn{2}{|c|}{0.72} & \multicolumn{2}{|c|}{0.49} \\
\hline
\end{tabular}


(d)

\begin{tabular}{|c|c|c|c|c|c|c|c|c|c|c|c|c|c|c|c|c|}
\hline \multirow{2}{*}{ M. C. } & \multicolumn{4}{|c|}{ Shoot } & \multicolumn{4}{|c|}{ Root } & \multicolumn{4}{|c|}{ Length } & \multicolumn{4}{|c|}{ Spike } \\
\hline & F. $\mathrm{m}$. & $\%$ & D. m. & $\%$ & F. m. & $\%$ & D. m. & $\%$ & Sh. & $\%$ & Ro. & $\%$ & D. m. & $\%$ & Length & $\%$ \\
\hline $90 \%$ & 7.9 & 100 & 2.8 & 100 & 3.6 & 100 & 0.80 & 100 & 64.8 & 100 & 24.8 & 100 & 2.0 & 100 & 18.5 & 100 \\
\hline $70 \%$ & 7.7 & 98.1 & 2.3 & 82.9 & 3.1 & 87.2 & 0.64 & 79.7 & 58.4 & 90.2 & 21.6 & 87.1 & $1.1^{* *}$ & 53.1 & $15^{\star \star}$ & 81.0 \\
\hline $50 \%$ & 5.6 & 70.6 & 1.9 & 68.1 & 2.4 & 66.9 & 0.52 & 64.7 & 52.4 & 80.8 & 22.8 & 91.9 & $0.38^{\star *}$ & 18.4 & $13^{* *}$ & 70.2 \\
\hline $30 \%$ & 4.2 & 53.2 & 1.5 & 51.4 & 1.4 & 39 & 0.28 & 34.7 & 33.6 & 51.9 & 12 & 48.4 & $0.24^{\star *}$ & 11.7 & $9^{* *}$ & 48.7 \\
\hline $90 \%+$ SA & 7.7 & 103.5 & 2.8 & 100 & 3.8 & 105.3 & 0.82 & 101.5 & 84 & 129.3 & 30 & 120.9 & 2.1 & 102.8 & 19 & 102.7 \\
\hline $70 \%+S A$ & 6.0 & 106.8 & 2.9 & 105.3 & 4.3 & 119.5 & 0.69 & 85.7 & 81 & 125 & 28 & 112.9 & $1.6^{* *}$ & 77.6 & $16^{\star *}$ & 86.5 \\
\hline $50 \%+\mathrm{SA}$ & 6.1 & 101 & 2.1 & 74.5 & 3.7 & 103.9 & 0.56 & 69.4 & 82 & 126.5 & 29 & 116.9 & $1.1^{* *}$ & 53.1 & $15^{\star *}$ & 81.1 \\
\hline $30 \%+\mathrm{SA}$ & 5.9 & 85.3 & 2.0 & 71.6 & 2.9 & 80.2 & 0.53 & 65.3 & 67 & 103.4 & 27 & 108.9 & $0.75^{\star *}$ & 36.7 & $12.5^{\star *}$ & 67.6 \\
\hline L. S. D. $0.05 \%$ & \multicolumn{2}{|c|}{0.17} & \multicolumn{2}{|c|}{0.15} & \multicolumn{2}{|c|}{0.15} & \multicolumn{2}{|c|}{0.02} & \multicolumn{2}{|c|}{1.0} & \multicolumn{2}{|c|}{0.87} & \multicolumn{2}{|c|}{0.13} & \multicolumn{2}{|c|}{0.75} \\
\hline
\end{tabular}

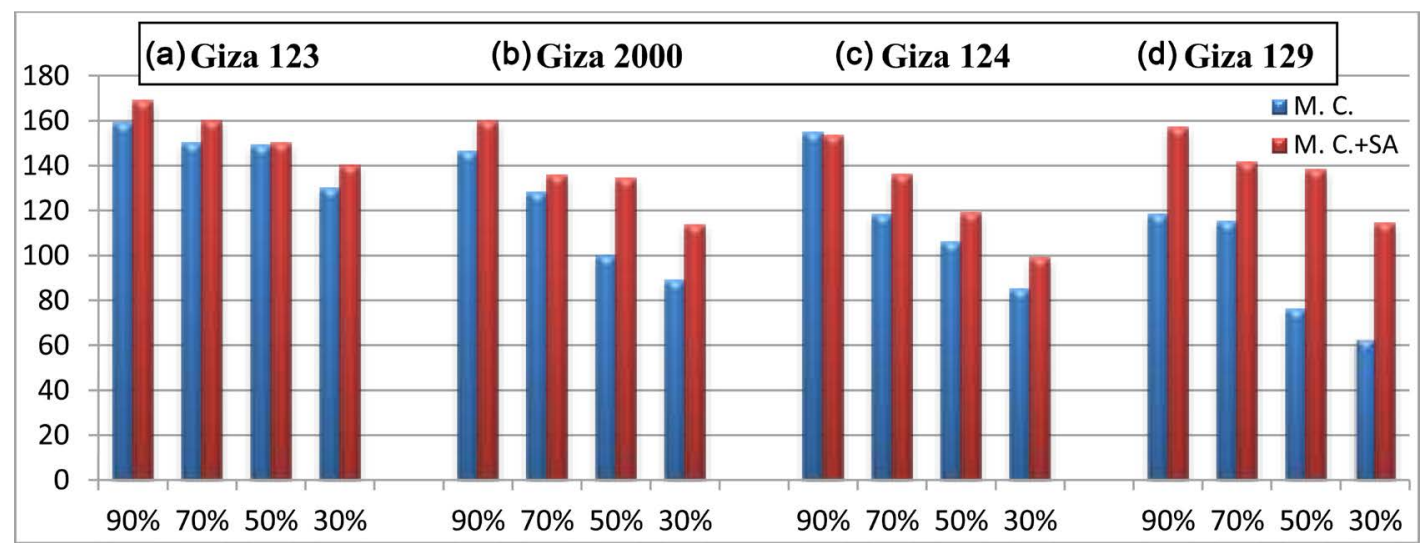

Figure 1. The response of Giza 124 (a), Giza 2000 (b), Giza 124 (c) and Giza 129 (d) barley genotypes to drought stress and interactive with SA treatments on leaf area at the final fruiting stage.

87.6\%, 58.3\%, 98.1 in Giza 2000 plant, 54.3\%, 50\%, 88.6\%, in Giza 124 plant, $54.1 \%, 38.9 \%, 74.1 \%$ in Giza 129 plant. Water content was reduced in shoot and root as decreasing M. C. levels in four tested genotypes, and the low values were recorded at $30 \% \mathrm{M}$. C. level (Table 2). The highest value in water content was recorded in Giza 123 while the lower one was observed in Giza 129. The percent of reduction at $30 \%$ M. C. level was $97.9 \%, 85.3 \%, 66.7 \%, 71.4 \%$, 85.8\%, 75\%, 39.2\% and 39.3\% in Giza 124, Giza 2000, Giza 124 and Giza 129 respectively (Table 2 ).

\subsection{Metabolities in Shoot and Root}

Soluble sugar and soluble protein significantly accumulated as decreasing moisture content in both shoot and root of Giza 123 (Table 3(a)). This more obvious in case of soluble sugar in root than in shoot and in case of soluble protein in shoot than in root. The high value was recorded at $30 \%$ M. C. in both contents, the percent of increase at that level was $114 \%, 160 \%, 150 \%$, and $200 \%$ compared with control pants. However amino acids become around the value of control in 


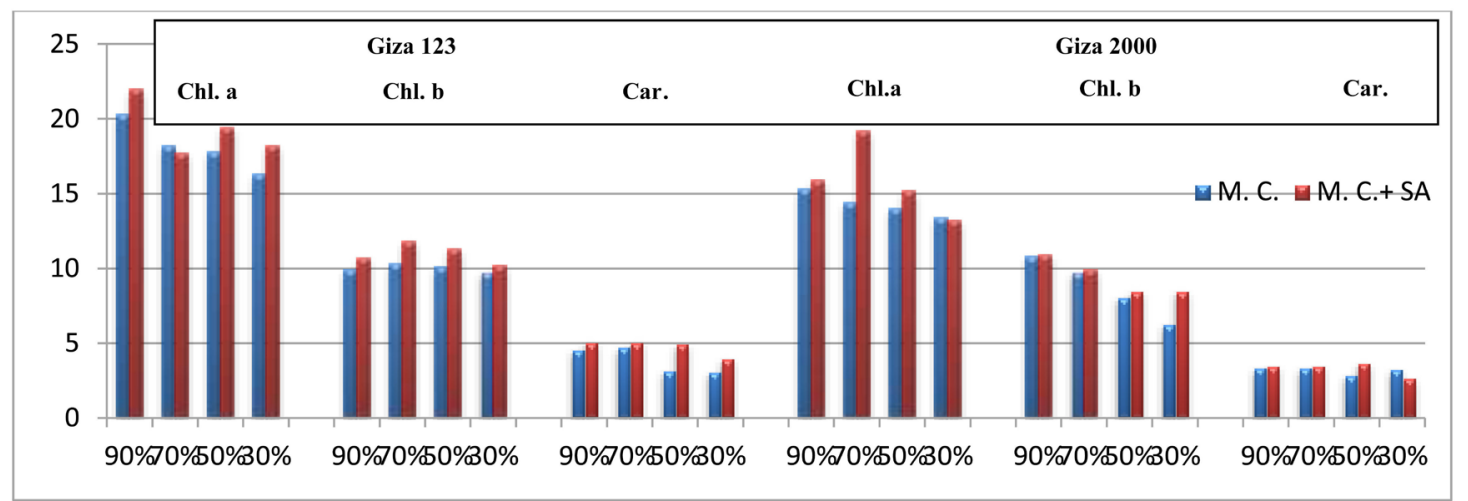

(a)

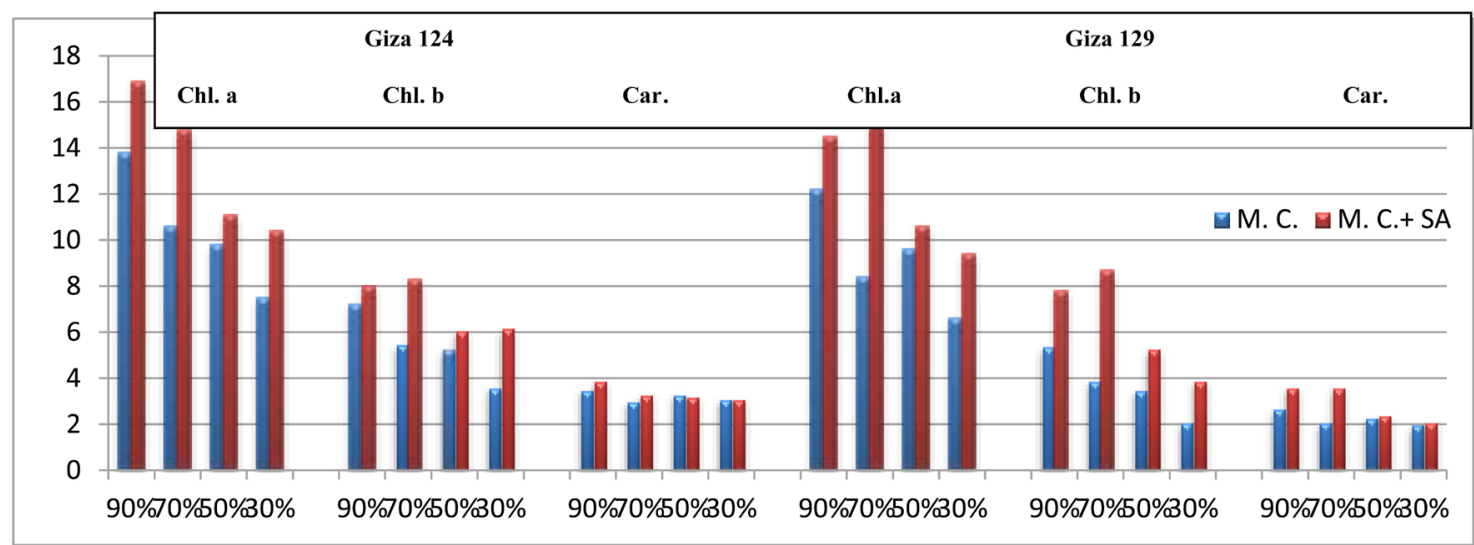

(b)

Figure 2. The response of Giza 123 (a), Giza 2000 (a), Giza 124 (b) and Giza 129 (b) barley genotypes to drought stress and interactive with SA treatments on pigment contents $\left(\mathrm{mg} \mathrm{g}^{-1} \mathrm{~d} . \mathrm{m}\right.$.).

Table 2. The response of Giza 123, Giiza 2000, Giza 124 and Giza 129 barley genotypes to drought stress and interactive with SA treatments on water content in shoot and root at the final fruiting stage.

\begin{tabular}{|c|c|c|c|c|c|c|c|c|c|c|c|c|c|c|c|c|}
\hline \multirow{2}{*}{$\begin{array}{l}\text { Treat. } \\
\text { M. C. }\end{array}$} & \multicolumn{4}{|c|}{ Giza 123} & \multicolumn{4}{|c|}{ Giza 2000} & \multicolumn{4}{|c|}{ Giza 124} & \multicolumn{4}{|c|}{ Giza 129} \\
\hline & Sh. & $\%$ & Ro. & $\%$ & Sh. & $\%$ & Ro. & $\%$ & Sh. & $\%$ & Ro. & $\%$ & Sh. & $\%$ & Ro. & $\%$ \\
\hline $90 \%$ & 4.9 & 100 & 3.4 & 100 & 3.6 & 100 & 2.1 & 100 & 3.4 & 100 & 3.2 & 100 & 5.1 & 100 & 2.8 & 100 \\
\hline $70 \%$ & 4.5 & 91 & 3.2 & 94.2 & 3.5 & 97.2 & 2.2 & 104 & 3.0 & 88.2 & 2.9 & 90.6 & 3.2 & 62.7 & 2.5 & 89.3 \\
\hline $50 \%$ & 4.8 & 97.9 & 3.0 & 88.2 & 3.1 & 86.1 & 1.8 & 85.7 & 3.0 & 88.2 & 2.5 & 78.1 & 3.7 & 72.5 & 1.9 & 67.9 \\
\hline $30 \%$ & 4.8 & 97.9 & 2.9 & 85.3 & 2.4 & 66.7 & 1.5 & 71.4 & 2.0 & 85.8 & 2.4 & 75 & 2.0 & 39.2 & 1.1 & 39.3 \\
\hline $90 \%+$ SA & 5.1 & 104.8 & 4.4 & 120.9 & 7.2 & 200 & 2.4 & 114.3 & 3.1 & 91.2 & 3.8 & 118.8 & 4.9 & 96.1 & 2.9 & 103.6 \\
\hline $70 \%+S A$ & 5.5 & 112.2 & 5.3 & 155.9 & 4.7 & 130.6 & 2.8 & 133.3 & 2.5 & 73.5 & 2.0 & 62.5 & 3.1 & 60.8 & 3.6 & 128.6 \\
\hline $50 \%+\mathrm{SA}$ & 4.4 & 89.8 & 4.9 & 144.1 & 5.0 & 138.9 & 2.8 & 133.3 & 3.4 & 100 & 4.3 & 134.4 & 4.0 & 78.4 & 2.5 & 89.3 \\
\hline $30 \%+\mathrm{SA}$ & 4.5 & 89.8 & 3.4 & 100 & 3.0 & 83.3 & 1.6 & 76.2 & 2.8 & 82.4 & 2.3 & 71.9 & 3.9 & 76.5 & 2.7 & 96.4 \\
\hline L. S. D. $0.05 \%$ & & 2.1 & & 1.1 & & 1.0 & & .9 & & .5 & & 1.8 & & 6 & & 1.1 \\
\hline
\end{tabular}

shoot at all moisture content levels, in root this effect was observed at $70 \% \mathrm{M}$. C. level, afterthat a smooth reduction was recorded in Giza 123 (Table 3(a)). There is a significant reduction in proline content in shoot, whereas a huge accumulation 
Table 3. The response of Giza 123 (a), Giza 2000 (b), Giza 124 (c) and Giza 129 (d) barley genotypes drought stress and interactive with SA treatments on soluble sugar $\left(\mathrm{mg} \mathrm{g}^{-1} \mathrm{~d}\right.$. $\mathrm{m}$.), soluble protein $\left(\mathrm{mg} \mathrm{g}^{-1} \mathrm{~d} . \mathrm{m}\right.$.), amino acids $\left(\mathrm{mg} \mathrm{g}^{-1} \mathrm{~d}\right.$. $\mathrm{m}$.) and proline content $\left(\mathrm{mg} \mathrm{g}^{-1} \mathrm{~d}\right.$. m.) of shoot and root at the final fruiting stage.

(a)

\begin{tabular}{|c|c|c|c|c|c|c|c|c|c|c|c|c|c|c|c|c|}
\hline \multirow{2}{*}{$\begin{array}{l}\text { Treat. } \\
\text { M. C. }\end{array}$} & \multicolumn{4}{|c|}{ Soluble sugar } & \multicolumn{4}{|c|}{ Soluble protein } & \multicolumn{4}{|c|}{ Amino acids } & \multicolumn{4}{|c|}{ Proline } \\
\hline & Sh. & $\%$ & Ro. & $\%$ & Sh. & $\%$ & Ro. & $\%$ & Sh. & $\%$ & Ro. & $\%$ & Sh. & $\%$ & Ro. & $\%$ \\
\hline $90 \%$ & 14.7 & 100 & 4.1 & 100 & 80 & 100 & 16.4 & 100 & 48.9 & 100 & 50.2 & 100 & 3.7 & 100 & 0.2 & 100 \\
\hline $70 \%$ & 15.8 & 107 & 4.8 & 118 & 100 & 125 & 16.8 & 102 & 52.2 & 106 & 54.1 & 108 & 3.6 & 98 & 0.8 & 100 \\
\hline $50 \%$ & 17.5 & 119 & 5.4 & 132 & 119 & 149 & 18.4 & 112 & 58.2 & 119 & 47.2 & 94 & 3.1 & 85 & 1.3 & 650 \\
\hline $30 \%$ & 16.7 & 114 & 6.5 & 160 & 120 & 150 & 32.8 & 200 & 53.3 & 109 & 44.7 & 89 & 6.3 & 173 & 1.1 & 550 \\
\hline $90 \%+\mathrm{SA}$ & 16.1 & 109 & 5.9 & 144 & 100 & 125 & 208 & 127 & 54.1 & 111 & 52.6 & 105 & 3.4 & 93 & 0.7 & 350 \\
\hline $70 \%+\mathrm{SA}$ & 19.3 & 131 & 7.1 & 173 & 113 & 141 & 24.4 & 149 & 58.7 & 120 & 56 & 111 & 2.1 & 75 & 0.3 & 150 \\
\hline $50 \%+\mathrm{SA}$ & 22.1 & 150 & 6.6 & 161 & 129 & 161 & 28.3 & 172 & 63.8 & 131 & 57.9 & 115 & 2.8 & 76 & 0.4 & 200 \\
\hline $30 \%+\mathrm{SA}$ & 28.8 & 196 & 6.9 & 171 & 127 & 159 & 29.5 & 180 & 67.3 & 138 & 65.2 & 130 & 3.4 & 93 & 0.3 & 150 \\
\hline L. S. D. $0.05 \%$ & \multicolumn{2}{|c|}{0.91} & \multicolumn{2}{|c|}{0.77} & \multicolumn{2}{|c|}{0.79} & \multicolumn{2}{|c|}{0.64} & \multicolumn{2}{|c|}{0.18} & \multicolumn{2}{|c|}{0.18} & \multicolumn{2}{|c|}{0.15} & \multicolumn{2}{|c|}{0.05} \\
\hline
\end{tabular}

(b)

\begin{tabular}{|c|c|c|c|c|c|c|c|c|c|c|c|c|c|c|c|c|}
\hline \multirow{2}{*}{$\begin{array}{l}\text { Treat. } \\
\text { M. C. }\end{array}$} & \multicolumn{4}{|c|}{ Soluble sugar } & \multicolumn{4}{|c|}{ Soluble protein } & \multicolumn{4}{|c|}{ Amino acid } & \multicolumn{4}{|c|}{ Proline } \\
\hline & Sh. & $\%$ & Ro. & $\%$ & Sh. & $\%$ & Ro. & $\%$ & Sh. & $\%$ & Ro. & $\%$ & Sh. & $\%$ & Ro. & $\%$ \\
\hline $90 \%$ & 18.5 & 100 & 7.6 & 100 & 83.2 & 100 & 18.8 & 100 & 47.2 & 100 & 51.4 & 100 & 3.9 & 100 & 0.19 & 100 \\
\hline $70 \%$ & 19.1 & 103 & 7.6 & 102 & 92 & 110 & 23.6 & 126 & 42.8 & 90.5 & 48 & 93 & 1.9 & 49 & 0.35 & 148 \\
\hline $50 \%$ & 20 & 107 & 7.8 & 103 & 118 & 142 & 34.4 & 183 & 52.0 & 110 & 50 & 97 & 2.2 & 56 & 0.58 & 284 \\
\hline $30 \%$ & 22 & 117 & 8.4 & 111 & 125 & 150 & 38.8 & 206 & 66 & 140 & 49 & 95 & 2.9 & 74 & 0.54 & 305 \\
\hline $90 \%+\mathrm{SA}$ & 20 & 107 & 8.0 & 102 & 84 & 101 & 21.6 & 115 & 53.5 & 113 & 55 & 107 & 5.5 & 141 & 0.36 & 189 \\
\hline $70 \%+S A$ & 23 & 123 & 9.0 & 114 & 99 & 119 & 24.4 & 130 & 57 & 120 & 58 & 112 & 5.0 & 129 & 0.43 & 226 \\
\hline $50 \%+\mathrm{SA}$ & 27 & 147 & 10 & 128 & 119 & 144 & 31.6 & 168 & 60 & 127 & 58.3 & 114 & 1.0 & 26 & 0.28 & 147 \\
\hline $30 \%+\mathrm{SA}$ & 31.4 & 170 & 8.4 & 112 & 128 & 154 & 30 & 158 & 67 & 142 & 61 & 118 & 1.4 & 37 & 0.45 & 237 \\
\hline L. S. D. $0.05 \%$ & \multicolumn{2}{|c|}{0.78} & \multicolumn{2}{|c|}{0.78} & \multicolumn{2}{|c|}{1.1} & \multicolumn{2}{|c|}{0.79} & \multicolumn{2}{|c|}{0.43} & \multicolumn{2}{|c|}{0.29} & \multicolumn{2}{|r|}{0.17} & \multicolumn{2}{|c|}{0.075} \\
\hline
\end{tabular}

(c)

\begin{tabular}{|c|c|c|c|c|c|c|c|c|c|c|c|c|c|c|c|c|}
\hline \multirow{2}{*}{ M. C. } & \multicolumn{4}{|c|}{ Soluble sugar } & \multicolumn{2}{|c|}{ Soluble } & \multicolumn{2}{|c|}{ Protein } & \multicolumn{4}{|c|}{ Amino acids } & \multicolumn{4}{|c|}{ Proline } \\
\hline & Sh. & $\%$ & Ro. & $\%$ & Sh. & $\%$ & Ro. & $\%$ & Sh. & $\%$ & Ro. & $\%$ & Sh. & $\%$ & Ro. & $\%$ \\
\hline $90 \%$ & 23.1 & 100 & 9.9 & 100 & 64 & 100 & 13.6 & 100 & 40 & 100 & 36 & 100 & 1.9 & 100 & 2.5 & 100 \\
\hline $70 \%$ & 16.1 & 70 & 8.3 & 84 & 94 & 147 & 15.2 & 112 & 40 & 100 & 39 & 108 & 1.0 & 53 & 2.2 & 87 \\
\hline $50 \%$ & 16.1 & 70 & 7.7 & 78 & 98 & 153 & 19.6 & 144 & 40 & 100 & 36 & 100 & 1.3 & 68 & 2.0 & 81 \\
\hline $30 \%$ & 14 & 60 & 8.5 & 86 & 119 & 186 & 36.0 & 265 & 46.3 & 117 & 29 & 80 & 1.6 & 84 & 2.3 & 92 \\
\hline $90 \%+\mathrm{SA}$ & 25 & 107 & 12 & 116 & 121 & 189 & 18 & 133 & 41 & 103 & 39 & 109 & 1.4 & 72 & 2.5 & 100 \\
\hline $70 \%+\mathrm{SA}$ & 22 & 94 & 11.4 & 115 & 148 & 232 & 18 & 129 & 43 & 109 & 39 & 108 & 0.82 & 43 & 2.2 & 88 \\
\hline $50 \%+S A$ & 19 & 81 & 13.4 & 136 & 139 & 217 & 26 & 192 & 46 & 119 & 43 & 120 & 1.4 & 72 & 2.1 & 83 \\
\hline $30 \%+S A$ & 18 & 78 & 13 & 130 & 137 & 214 & 34 & 253 & 49 & 124 & 43 & 121 & 1.5 & 77 & 3.7 & 151 \\
\hline L. S. D. $0.05 \%$ & \multicolumn{2}{|c|}{0.67} & \multicolumn{2}{|c|}{0.67} & \multicolumn{2}{|c|}{1.3} & \multicolumn{2}{|c|}{0.69} & \multicolumn{2}{|c|}{0.52} & \multicolumn{2}{|c|}{084} & \multicolumn{2}{|c|}{0.14} & \multicolumn{2}{|c|}{0.13} \\
\hline
\end{tabular}


(d)

\begin{tabular}{|c|c|c|c|c|c|c|c|c|c|c|c|c|c|c|c|c|}
\hline \multirow{2}{*}{ M. C. } & \multicolumn{4}{|c|}{ Soluble sugar } & \multicolumn{4}{|c|}{ Soluble Protein } & \multicolumn{4}{|c|}{ Amino acid } & \multicolumn{4}{|c|}{ Proline } \\
\hline & Sh. & $\%$ & Ro. & $\%$ & Sh. & $\%$ & Ro. & $\%$ & Sh. & $\%$ & Ro. & $\%$ & Sh. & $\%$ & Ro. & $\%$ \\
\hline $90 \%$ & 18 & 100 & 9 & 100 & 43 & 100 & 16 & 100 & 32 & 100 & 37 & 100 & 2.2 & 100 & 1.4 & 100 \\
\hline $70 \%$ & 16 & 89 & 8.1 & 91 & 60 & 141 & 19 & 122 & 49 & 153 & 36 & 98 & 2.5 & 115 & 2.6 & 186 \\
\hline $50 \%$ & 14 & 81 & 3.7 & 42 & 64 & 150 & 19 & 118 & 51 & 140 & 46 & 125 & 3.6 & 165 & 2.8 & 199 \\
\hline $30 \%$ & 13 & 71 & 2.7 & 31 & 69 & 162 & 22 & 139 & 45 & 159 & 46 & 125 & 3.6 & 166 & 2.8 & 199 \\
\hline $90 \%+\mathrm{SA}$ & 17 & 99 & 9.2 & 102 & 62 & 146 & 18 & 114 & 37 & 117 & 45 & 121 & 2.7 & 123 & 0.47 & 33 \\
\hline $70 \%+S A$ & 23 & 131 & 9.0 & 98 & 79 & 184 & 28 & 173 & 44 & 139 & 45 & 123 & 1.8 & 84 & 0.93 & 66 \\
\hline $50 \%+\mathrm{SA}$ & 20 & 111 & 4.3 & 48 & 81 & 190 & 24 & 150 & 48 & 150 & 46 & 125 & 4.0 & 175 & 0.62 & 44 \\
\hline $30 \%+\mathrm{SA}$ & 21 & 120 & 3.7 & 42 & 104 & 244 & 27 & 170 & 53 & 167 & 52 & 140 & 3.1 & 144 & 0.63 & 45 \\
\hline L. S. D. $0.05 \%$ & \multicolumn{2}{|c|}{0.49} & \multicolumn{2}{|c|}{0.45} & \multicolumn{2}{|c|}{0.73} & \multicolumn{2}{|c|}{0.60} & \multicolumn{2}{|c|}{0.51} & \multicolumn{2}{|c|}{0.57} & \multicolumn{2}{|c|}{0.13} & \multicolumn{2}{|c|}{0.11} \\
\hline
\end{tabular}

was induced in root Giza 123 plant reach 3-folds at 30\% M. C. levels (Table 3(a)). Decreasing moisture content induced no significant change in soluble sugar in Giza 2000 till 50\% M. C. level and then a slight increase was recorded in both shoot and root (Table 3(b)). However a significant accumulation in soluble protein was detected in shoot and root. The maximum percent value was recorded at $30 \%$ M. C. level reach a $150 \%$ and $206 \%$ compared with control plants. While decreasing moisture content induced an increasing effect in amino acids content in shoot while a slight decreasing effect was induced in root (Table $3(b))$. There is a two situation in case of proline content, a decreasing effect in shoot was induced and in root an increasing effect was exhibited (Table 3(b)). While a marked decreasing effect was occurred in soluble sugar in shoot and root of cv. Giza 124, an increasing effect was induced in soluble protein of both organs reach a high percent value at 30\% M. C. level 186\% and 265\% (Table $3(\mathrm{c}))$. Amino acids give the value of control up to $50 \% \mathrm{M}$. C. level, then a smooth increasing effect in shoot and a reduction in root was recorded (Table $3(c))$. A surprise position was detected in proline content decreasing effect was observed in shoot and root of Giza 124 plant (Table 3(c)). The data in Table 3(d) revealed that soluble sugar in shoot and root of Giza 129 was significantly decreased as decreasing moisture content reach a low value at $30 \%$ M. C. level. This reduction was more pronounced in root than shoot organ. Soluble protein and amino acids were markedly elevated with decreasing moisture content. The percent of increase at $30 \% \mathrm{M}$. C. level was $162 \%, 139 \%, 159 \%$ and $125 \%$ of both content in shoot and root compared with control plants control. Proline content was markedly accumulated as decreasing soil moisture content in shoot and root of Giza 129 , reach a high value at $30 \% \mathrm{M}$. C. level 2-folds compared with control plants (Table $3(\mathrm{~d})$ ). $\mathrm{K}^{+}, \mathrm{Ca}^{++}$, and $\mathrm{Mg}^{++}$were generally remain unchanged in shoot and root of both barley Giza 123 and Giza 2000 (Figure 3(a)). Except of this trend root $\mathrm{K}^{++}$and $\mathrm{Ca}^{++}$in root of Giza 2000 and $\mathrm{Ca}^{++}$in both organs of Giza 123 tended to increase as decreasing M. C. level. $\mathrm{K}^{+}$content tended to 
decrease in both shoot and root of Giza 124 (Figure 3(b)). While $\mathrm{Ca}^{++}$content decreased in shoot, increase in root of Giza 124, moreover $\mathrm{Mg}^{++}$do not change with increasing drought stress in shoot while tended to increase in root (Figure 3(b)). In Giza $129 \mathrm{~K}^{+}$content was lowered as decreasing M. C. level while $\mathrm{Ca}^{++}$was increased in shoot, in root this content remain unchanged (Figure $3(\mathrm{~b})$ ). $\mathrm{Mg}^{++}$content tended to decreased in shoot while tended to increase in root.

\subsection{Metabolities in Spikes}

Soluble sugar, soluble protein, amino acids and proline tended to smoothly increase especially at 50\% and 70\% M. C. in spikes of Giza 123 (Table 4(a)). In spikes of Giza 2000 drought stress increased soluble sugar and soluble protein while amino acids tended to exhibit an irregular pattern and a reduction in proline content was recorded (Table 4(a)). A slight accumulation in soluble sugar, soluble protein and amino acids in spikes of Giza 124 (Table 4(b)) was induced. Moreover a hug increases in soluble sugar and proline content was recorded in spikes of Giza 129 (Table 4(b)). The activation was reached 2.5-folds in soluble sugar and 8-folds in proline content in spikes of Giza 129 (Table 4(b)). On the other side a small increase in soluble protein and amino acids in spikes of Giza 124 was induced. In spikes of Giza 123 both $\mathrm{K}^{+}$and $\mathrm{Mg}^{++}$were markedly increased as increasing drought stress, reached 2 -folds at $50 \% \mathrm{M}$. C. level in case of $\mathrm{K}^{+}$and at $30 \% \mathrm{M}$. C. level in case of $\mathrm{Mg}^{++}$(Table 5(a)). While $\mathrm{Ca}^{++}$increased at $70 \%$ M. C., decreased at $50 \%$ and $30 \%$ M. C. levels compared with control plants (Table 5(a)). $\mathrm{Ca}^{++}$and $\mathrm{Mg}^{++}$were significantly increased in Giza 2000 especially at $70 \%$ and $50 \%$ M. C. and gave the same values, however $\mathrm{K}^{+}$was smoothly decreased at 70\% and 50\% M. C. levels and dramatically reduced at 30\% M. C. level (Table 4(a)). Drought stress induced reduction in $\mathrm{K}^{+}, \mathrm{Ca}^{++}$in both Giza 124 and Giza 129 and $\mathrm{Mg}^{++}$in Giza 124 especially at lower moisture content (50\% and $30 \%$ M. C.) (Table 5(b)). Except of this trend $\mathrm{Mg}^{++}$in Giza 129 significantly increased compared with control plant (Table 5(b)). Osmotic pressure was increased in shoot, root and spike of four barley tested genotypes with varied degree, moreover root organ was the lowest values than shoot and spike organs (Figures 4(a)-(d)). The percent of increase at 30\% M. C. was 132.6\%, 117.7\% and $115.5 \%$ in shoot, root and spike of Giza 123, in Giza 2000 it was $136.4 \%$, $126.3 \%, 127.8 \%$, in Giza 124 it was $134.5 \%, 105.5 \%, 106.3 \%$ and finally in Giza 129 this percent was $135.2 \%, 113.0 \%$ and $139.9 \%$ compared with control plants.

\subsection{SA Application}

SA application was markedly enhanced the production of fresh, dry mater, length of shoot and root with varied degree according to each tested barley genotype (Tables 1(a)-(d)). The medium percent of different moisture content levels in fresh, dry matter and length of shoot and root after spraying with $0.5 \mathrm{mM}$ 

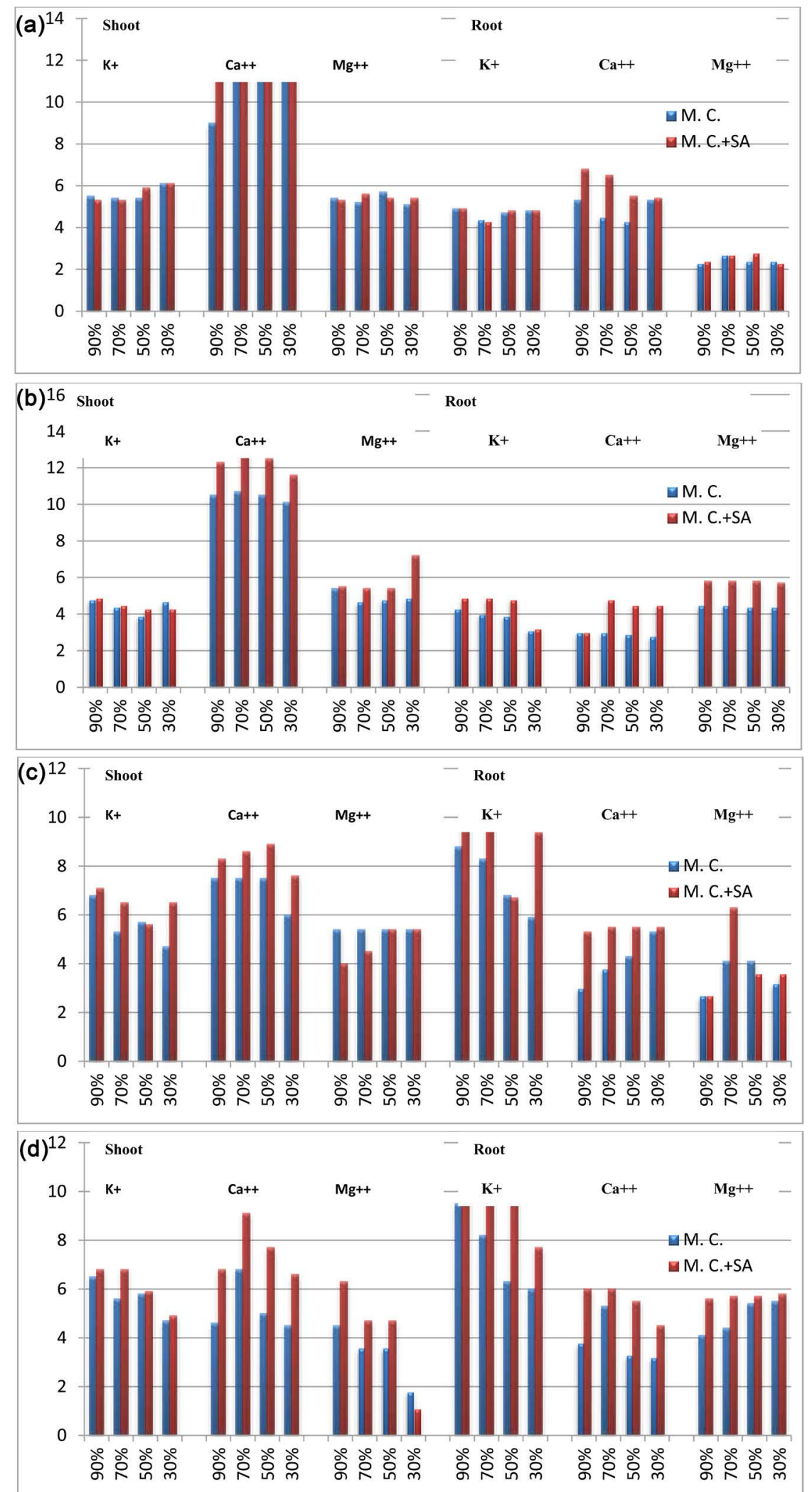

Figure 3. The response of Giza 123 (a), Giza 2000 (b), Giza 124 (c) and Giza 129 (d) barley genotypes to drought stress and interactive with SA treatments on $\mathrm{K}^{+}, \mathrm{Ca}^{++}$and $\mathrm{Mg}^{++}$contents ( $\mathrm{mg} \mathrm{g}^{-1} \mathrm{~d}$. m.) of shoot and root at the final fruiting stage. 
Table 4. The response of Giza 123 (a), Giza 2000 (a), Giza 124 (b) and Giza 129 (b) barley genotypes to drought stress and interac-

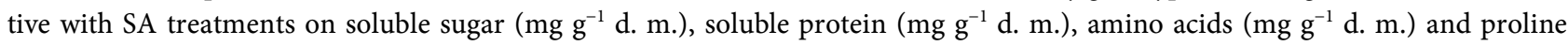
content ( $\mathrm{mg} \mathrm{g}^{-1} \mathrm{~d} . \mathrm{m}$.), in spikes at the final fruiting stage.

(a)

\begin{tabular}{|c|c|c|c|c|c|c|c|c|c|c|c|c|c|c|c|c|c|}
\hline \multirow[b]{2}{*}{ Treat. } & \multicolumn{9}{|c|}{ Giza 123} & \multicolumn{8}{|c|}{ Giza. 2000} \\
\hline & M. C. & $\begin{array}{l}\text { Sol. } \\
\text { sug. }\end{array}$ & $\%$ & $\begin{array}{l}\text { Sol. } \\
\text { prot. }\end{array}$ & $\%$ & Am. acid & $\%$ & Prol. & $\%$ & $\begin{array}{l}\text { Sol. } \\
\text { sug. }\end{array}$ & $\%$ & $\begin{array}{l}\text { Sol. } \\
\text { prot. }\end{array}$ & $\%$ & $\begin{array}{l}\text { Am. } \\
\text { acid }\end{array}$ & $\%$ & Prol. & $\%$ \\
\hline \multirow{8}{*}{ Control } & $90 \%$ & 52.5 & 100 & 119 & 100 & 42.9 & 100 & 0.7 & 100 & 48 & 100 & 107 & 100 & 48.2 & 100 & 0.69 & 100 \\
\hline & $70 \%$ & $63^{*}$ & 119.1 & $125^{\star *}$ & 104 & $40.2^{\star \star}$ & 93.2 & 0.65 & 93 & $99.5^{* *}$ & 207 & $114^{* *}$ & 107 & $46.9^{* *}$ & 97 & $0.25^{* *}$ & 36 \\
\hline & $50 \%$ & $80^{* *}$ & 152 & $134^{\star \star}$ & 112 & $50^{\star *}$ & 115 & $1.4^{* \star}$ & 200 & $61^{\star \star}$ & 127 & $127^{\star *}$ & 119 & $41.4^{\star \star}$ & 86 & 0.25 & 36 \\
\hline & $30 \%$ & $60^{* *}$ & 115 & $139^{* *}$ & 116 & $50^{\star *}$ & 115 & $0.9^{* *}$ & 129 & $85.5^{\star *}$ & 178 & $127^{\star *}$ & 119 & $49.2^{\star *}$ & 102 & $0.57^{\star *}$ & 83 \\
\hline & $\begin{array}{c}90 \%+ \\
\mathrm{SA}\end{array}$ & $62.5^{* *}$ & 119 & $103^{* *}$ & 86.2 & $46.9^{\star *}$ & 109 & $0.3^{* *}$ & 43 & 55 & 115 & 108 & 101 & $50.1^{* *}$ & 104 & $0.53^{\star *}$ & 77 \\
\hline & $\begin{array}{c}70 \%+ \\
\mathrm{SA}\end{array}$ & $82^{* *}$ & 156 & $128^{\star *}$ & 107 & $47.1^{* *}$ & 110 & $0.4^{* *}$ & 57 & $62^{\star *}$ & 129 & $102^{* *}$ & 95 & $52^{* *}$ & 108 & $0.34^{\star *}$ & 49 \\
\hline & $\begin{array}{c}50 \%+ \\
\mathrm{SA}\end{array}$ & 46.5 & 89 & $130^{\star *}$ & 109 & $51.1^{* *}$ & 119 & 0.7 & 100 & $85^{\star *}$ & 177 & $102^{\star *}$ & 95 & $50.3^{\star *}$ & 104 & $0.2^{* *}$ & 29 \\
\hline & $\begin{array}{c}30 \%+ \\
\mathrm{SA}\end{array}$ & 47.5 & 91 & $157^{\star *}$ & 132 & $42.3^{* *}$ & 99 & $0.5^{* *}$ & 71 & $105^{\star *}$ & 219 & $117^{\star *}$ & 109 & $75^{* *}$ & 155 & $0.54^{\star *}$ & 78 \\
\hline L. S. D. & 0.05 & \multicolumn{2}{|c|}{1.0} & \multicolumn{2}{|c|}{1.1} & \multicolumn{2}{|l|}{0.24} & \multicolumn{2}{|c|}{0.08} & \multicolumn{2}{|c|}{0.76} & \multicolumn{2}{|c|}{1.6} & \multicolumn{2}{|c|}{0.58} & \multicolumn{2}{|c|}{0.08} \\
\hline
\end{tabular}

(c)

\begin{tabular}{|c|c|c|c|c|c|c|c|c|c|c|c|c|c|c|c|c|c|}
\hline \multirow[b]{2}{*}{ Treat. } & \multirow[b]{2}{*}{ M. C. } & \multicolumn{8}{|c|}{ Giza 124} & \multicolumn{8}{|c|}{ Giza 129} \\
\hline & & $\begin{array}{l}\text { Sol. } \\
\text { sug. }\end{array}$ & $\%$ & Sol. prot. & $\%$ & $\begin{array}{l}\text { Am. } \\
\text { acid }\end{array}$ & $\%$ & Prol. & $\%$ & Sol. sug. & $\%$ & $\begin{array}{l}\text { Sol. } \\
\text { prot. }\end{array}$ & $\%$ & $\begin{array}{l}\text { Am. } \\
\text { acid }\end{array}$ & $\%$ & Prol. & $\%$ \\
\hline \multirow{8}{*}{ Control } & $90 \%$ & 35 & 100 & 119 & 100 & 33.9 & 100 & 1.25 & 100 & 22.5 & 100 & 101 & 100 & 43 & 100 & 0.62 & 100 \\
\hline & $70 \%$ & $57^{\star *}$ & 163 & 121 & 102 & $31^{* *}$ & 91 & $0.56^{\star *}$ & 45 & $28.5^{* *}$ & 127 & $107^{\star *}$ & 106 & 43 & 100 & $0.99^{* *}$ & 160 \\
\hline & $50 \%$ & $40^{\star *}$ & 114 & $134^{\star \star}$ & 112 & $36^{* *}$ & 106 & $0.91^{* *}$ & 73 & $56.5^{\star *}$ & 251 & $115^{\star \star}$ & 114 & $46^{* *}$ & 108 & $3.5^{\star *}$ & 564 \\
\hline & $30 \%$ & 31 & 89 & $135^{\star *}$ & 113 & $39^{* *}$ & 115 & $0.83^{* *}$ & 66 & $63.5^{* *}$ & 282 & $117^{\star \star}$ & 116 & $51^{\star *}$ & 120 & $5.4^{* *}$ & 871 \\
\hline & $\begin{array}{c}90 \%+ \\
\text { SA }\end{array}$ & 38 & 109 & $124^{\star \star}$ & 104 & $38^{* *}$ & 111 & $0.44^{\star *}$ & 35 & $49.5^{* *}$ & 220 & $109^{* *}$ & 108 & $49^{* *}$ & 115 & $0.68^{\star *}$ & 110 \\
\hline & $\begin{array}{c}70 \%+ \\
\text { SA }\end{array}$ & $59^{* *}$ & 167 & $101^{* *}$ & 85 & $42^{* *}$ & 124 & $0.84^{\star *}$ & 67 & $67.5^{* *}$ & 330 & $137^{\star *}$ & 137 & $45^{\star *}$ & 106 & $1.9^{* *}$ & 306 \\
\hline & $\begin{array}{c}50 \%+ \\
\text { SA }\end{array}$ & $66^{* *}$ & 168 & $116^{* *}$ & 97 & $39^{* *}$ & 114 & $0.57^{\star \star *}$ & 46 & $68.5^{* *}$ & 304 & $112^{\star *}$ & 111 & $36^{* *}$ & 84 & $1.7^{* *}$ & 274 \\
\hline & $\begin{array}{c}30 \%+ \\
\text { SA }\end{array}$ & $77^{* *}$ & 220 & $106^{* *}$ & 89 & $37^{* *}$ & 108 & $0.84^{\star \star}$ & 67 & $71^{\star *}$ & 315 & $140^{\star *}$ & 140 & $58^{* *}$ & 131 & $2.4^{* *}$ & 435 \\
\hline $\begin{array}{c}\text { L. S. D. } \\
0.05 \%\end{array}$ & & \multicolumn{2}{|c|}{0.35} & \multicolumn{2}{|l|}{1.5} & \multicolumn{2}{|c|}{0.71} & \multicolumn{2}{|c|}{0.09} & \multicolumn{2}{|c|}{0.36} & \multicolumn{2}{|c|}{1.5} & \multicolumn{2}{|c|}{0.47} & \multicolumn{2}{|c|}{0.08} \\
\hline
\end{tabular}

SA was $109.5 \%, 132.3 \%, 129.9 \%, 120.3 \%, 96.3 \%, 97.3 \%$, in Giza 123. In Giza 2000 this percent of increase was 142.5, 136.7, 112.9\%, 103.9\%, 90.3\%, 85.6\%. However in Giza 124 it was 101.6\%, 100.7\%, 102.4\%, 99.9\%, 94.4\%, 105.5\%, and in Giza 129 this increasing percent was $99.2 \%, 87.9 \%, 102.2 \%, 80.5 \%, 121.1 \%$, 
Table 5. The response of cv. Giza 123 (a), cv. 2000 (a), cv. Giza 124 (b) and cv. Giza 129 (b) barley genotypes to drought stress and interactive with SA treatments on $\mathrm{K}^{+}, \mathrm{Ca}^{++}$and $\mathrm{Mg}^{++}\left(\mathrm{mg} \mathrm{g}^{-1} \mathrm{~d}\right.$. m.), in spikes at the final fruiting stage.

(a)

\begin{tabular}{|c|c|c|c|c|c|c|c|c|c|c|c|c|}
\hline \multirow{2}{*}{ M. C. } & \multicolumn{6}{|c|}{ Giza 123} & \multicolumn{6}{|c|}{ Giza 2000} \\
\hline & $\mathrm{K}^{+.}$ & $\%$ & $\mathrm{Ca}^{++}$ & $\%$ & $\mathrm{Mg}^{++}$ & $\%$ & $\mathrm{~K}^{++.}$ & $\%$ & $\mathrm{Ca}^{++}$ & $\%$ & $\mathrm{Mg}^{++}$ & $\%$ \\
\hline $90 \%$ & 0.8 & 100 & 3.8 & 100 & 1.4 & 100 & 1.33 & 100 & 1.5 & 100 & 2.7 & 100 \\
\hline $70 \%$ & $1.1^{* *}$ & 141 & $6^{* *}$ & 160 & 1.8 & 133 & 1.3 & 98 & $3^{* *}$ & 200 & $3.6^{* *}$ & 133 \\
\hline $50 \%$ & $1.8^{\star *}$ & 221 & $3^{* *}$ & 80 & 1.8 & 133 & 1.3 & 96 & $3^{* *}$ & 200 & $3.6^{* *}$ & 133 \\
\hline $30 \%$ & 0.73 & 91 & $3^{* *}$ & 80 & $2.7^{\star \star}$ & 200 & $1^{* *}$ & 75 & 1.5 & 100 & 2.7 & 100 \\
\hline $90 \%+\mathrm{SA}$ & $1.8^{\star *}$ & 229 & $6^{* *}$ & 160 & $4.5^{\star *}$ & 333 & $1.7^{* *}$ & 127 & $2.3^{* *}$ & 150 & 2.7 & 100 \\
\hline $70 \%+S A$ & $1.9^{* *}$ & 246 & $4.5^{* *}$ & 120 & $2.7^{* *}$ & 290 & 1.4 & 108 & 1.5 & 100 & 2.7 & 100 \\
\hline $50 \%+\mathrm{SA}$ & $2.7^{\star *}$ & 334 & $4.5^{\star *}$ & 120 & 1.8 & 133 & 1.3 & 98 & $3^{* *}$ & 200 & 2.7 & 100 \\
\hline $30 \%+\mathrm{SA}$ & 0.8 & 100 & $2.3^{* *}$ & 60 & 1.3 & 132 & 1.1 & 85 & $4.5^{\star *}$ & 300 & 2.7 & 100 \\
\hline L.S.D. $0.05 \%$ & \multicolumn{2}{|c|}{0.22} & \multicolumn{2}{|c|}{0.41} & \multicolumn{2}{|c|}{0.41} & \multicolumn{2}{|c|}{0.24} & \multicolumn{2}{|c|}{0.38} & \multicolumn{2}{|c|}{0.55} \\
\hline
\end{tabular}

(b)

\begin{tabular}{|c|c|c|c|c|c|c|c|c|c|c|c|c|}
\hline \multirow{2}{*}{ M. C. } & \multicolumn{6}{|c|}{ Giza 124} & \multicolumn{6}{|c|}{ Giza 129} \\
\hline & $\mathrm{K}^{+}$ & $\%$ & $\mathrm{Ca}^{++}$ & $\%$ & $\mathrm{Mg}^{++}$ & $\%$ & $\mathrm{~K}^{++}$ & $\%$ & $\mathrm{Ca}^{++}$ & $\%$ & $\mathrm{Mg}^{++}$ & $\%$ \\
\hline $90 \%$ & 1.6 & 100 & 4.5 & 100 & 2.7 & 100 & 2.0 & 100 & 3.8 & 100 & 1.4 & 100 \\
\hline $70 \%$ & $2^{\star *}$ & 125 & $4 . .5$ & 100 & 2.7 & 100 & $1.2^{\star *}$ & 74 & $3^{* *}$ & 80 & $1.8^{* *}$ & 133 \\
\hline $50 \%$ & 1.3 & 83 & $3^{* *}$ & 67 & $1.8^{* *}$ & 67 & $1.1^{\star *}$ & 56 & $3^{* *}$ & 80 & $3.6^{* *}$ & 267 \\
\hline $30 \%$ & $1.2^{* \star}$ & 72 & $1.5^{\star \star}$ & 33 & $0.9^{* *}$ & 33 & $0.53^{\star *}$ & 26 & $2.3^{* *}$ & 60 & $3.2^{* \star}$ & 233 \\
\hline $90 \%+\mathrm{SA}$ & 1.7 & 104 & $1.5^{* *}$ & 33 & $1.8^{* *}$ & 67 & $0.67^{\star *}$ & 33 & $1.5^{\star *}$ & 40 & $2.7^{\star *}$ & 200 \\
\hline $70 \%+S A$ & $2^{\star *}$ & 125 & $1.5^{* *}$ & 17 & $0.9^{* *}$ & 33 & $0.6^{* *}$ & 29 & $4.5^{* *}$ & 120 & $2.7^{* *}$ & 200 \\
\hline $50 \%+\mathrm{SA}$ & 1.3 & 79 & $0.75^{\star *}$ & 17 & $1 . .8^{* *}$ & 67 & $0.57^{\star *}$ & 28 & $3^{* *}$ & 80 & 1.8 & 133 \\
\hline $30 \%+\mathrm{SA}$ & $1.1^{* *}$ & 67 & $0.75^{\star *}$ & 17 & $0.9^{* *}$ & 33 & $0.47^{* *}$ & 23 & $1.5^{* *}$ & 40 & $0.9^{* *}$ & 67 \\
\hline L. S. D. $0.05 \%$ & \multicolumn{2}{|c|}{0.26} & \multicolumn{2}{|c|}{0.29} & \multicolumn{2}{|c|}{0.27} & \multicolumn{2}{|c|}{0.32} & \multicolumn{2}{|c|}{0.29} & \multicolumn{2}{|c|}{0.27} \\
\hline
\end{tabular}

$114.9 \%$ compared with unsprayed barley plants. SA increased water content and leaf area at all tested barley cultivars, this effect was more pronounced in Giza 129, Giza 2000, and Giza 124 than Giza 123 especially in leaf area parameter (Table 2 and Figure 1). SA application enhanced the synthesis of photosynthetic pigments in four barley genotypes (Figure 2(a) \& Figure 2(b)). This activation effect was more obvious in case of Chl. a in Giza 123 and Giza 2000 (Figure 2(a)) and in case of production Chl. a and Chl.b in both Giza 124 and Giza 129 (Figure 2(b)). Spraying vegetative parts with SA was markedly increased the soluble sugar, soluble protein and amino acids of both shoot and root of four barley cultivars. The medium percent of increase of the previous parameters in plants spraying with SA in Giza 123 was 146.5\%, 162.3\%, 146.5\%, 157\%, 125\%, $115.3 \%$, was in shoot and root (Table 3(a)). This value in Giza 2000 was $136.8 \%$, $114 \%, 129.5 \%, 142.8 \%, 125.5 \%, 112.8 \%$, (Table 3(b)). In Giza124 it was 90\%, 
$124.5 \%, 213 \%, 176.8 \%, 113.8 \%, 114.5 \%$ (Table 3(c)). In Giza 129 it was $115.3 \%$, $72.5 \%, 191 \%, 151.8 \%, 143.3 \%, 127.3 \%$ compared with control plants (Table $3(d))$. On the other side SA application lowered the accumulation of proline in shoot and root of four barley genotypes (Tables 3(a)-(d)). SA application induced unchanged in soluble sugar, a slight accumulation in soluble protein and amino acids, while a reduction in proline in spikes of Giza 123 was recorded (Table 4(a)). Activation in the accumulation of soluble sugar and amino acids especially at $30 \% \mathrm{M}$. C. and a reduction in proline was recorded in spikes of Giza 2000 (Table 4(a)). SA treatment increased soluble sugar, unchanged in amino acids content while a reduction was induced in proline in spikes of Giza 124 (Table 4(b)). SA activated the accumulation of following contents, soluble sugar reached 3-folds, protein and proline this with unchanged effet in amino acids as compared with $90 \%$ M. C. (Table $4(\mathrm{~b})$ ). While spraying vegetative parts with SA induced no significant change in $\mathrm{K}^{+}, \mathrm{Ca}^{++}$, and $\mathrm{Mg}^{++}$in shoot and root of Giza 123. While significantly increased $\mathrm{K}^{+}, \mathrm{Ca}^{++}$and $\mathrm{Mg}^{++}$in shoot and root of Giza 2000 was reorded (Table 5(a) \& Table 5(b)). SA application enhanced accumulation of $\mathrm{K}^{+}, \mathrm{Ca}^{++}$in both shoot and root of Giza 124 and $\mathrm{K}^{+}, \mathrm{Ca}^{++}$and $\mathrm{Mg}^{++}$in Giza 129. SA increased $\mathrm{K}^{+}$reached 3-folds at 50\% M. C. level. $\mathrm{Ca}^{++}$reached 2-folds at 30\% M. C. and $\mathrm{Mg}^{++}$in spikes of Giza 123 (Table 5(a)). SA application resulted unchanged in $\mathrm{K}^{+}, \mathrm{Ca}^{++}$and $\mathrm{Mg}^{++}$in both Giza 124 and Giza 129 (Table 5(b)). Except of this position $\mathrm{Mg}^{++}$increased as decreasing M. C. in spikes of Giza 129, the high value was recorded at 30\% M. C. (Table 5(b)). SA treatment was activated the value of OP in four tested barley genotypes, this effect was more pronounced in shoot and spike of Giza 129 than other organs of other genotypes (Figures 4(a)-(d)). The percent of activation at lowest value of moisture content (30\% M. C.) was $144.2 \%, 137.9 \%, 119.4 \%$ in shoot, root and spike of Giza 123. In Giza 2000, it was 144.7\%, 170.6\%, 146.3\%, in Giza 124 it was $151.4 \%$, $131.2 \%, 113.4$ and finally in Giza 129 this percent was $177.9 \%, 125.3 \%$ and $156.9 \%$ as compared with control plants.

\section{Discussion}

Previous data can be demonstrated that four barley genotypes varied in their drought tolerance according to their efficiency and tested organs. It can be observed that fresh, dry matter and length of shoot and root decreased as decreasing M. C., the percent of reduction at 30\% M. C. level as follows $96.9 \%, 96 \%$, $84 \%, 72.4 \%, 80 \%, 80 \%$, in Giza 123. In Giza 2000, it was 69.4\%, 81.7\%, 66.7\%, $52.0 \%, 67.2 \%, 68.2 \%$, in Giza 124 it was $63.9 \%, 63.4 \%, 43.7 \%, 66.6 \%, 65.4 \%, 68 \%$ and finally in Giza 129 this percent of reduction was 53.2\%, 51.4\%, 39\%, 34.7, $51.9 \%, 48.4 \%$ compared with control plants. This supported by spike production the net result of cultivation, the percent of dry matter and length of spike was $52 \%, 79.4 \%$, 41.3\%, 63.9\%, 31.6\%, 61.2\%, 11.7\%, 48.7\% in Giza 123, Giza 2000, Giza 124 and Giza 129 respectively. Also, leaf area and pigment production were markedly decreased according to genotype tolerance, it run parallel with fresh 
(a)

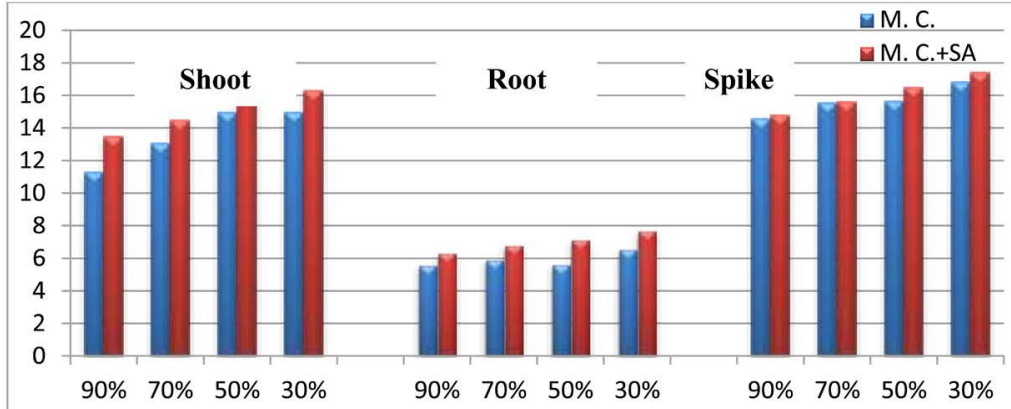

(b)

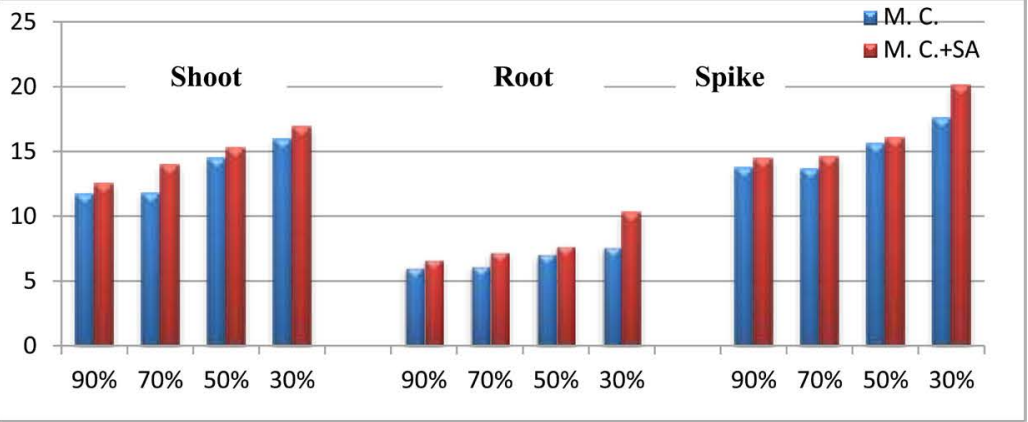

(c)

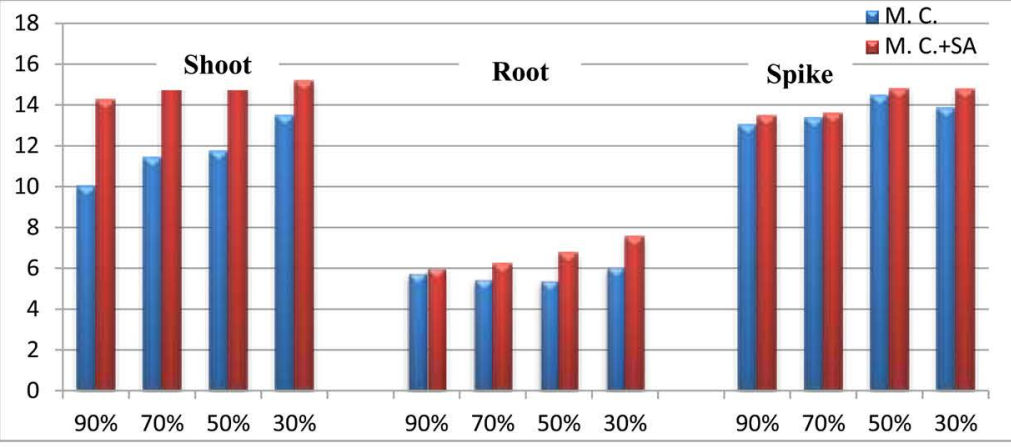

(d)

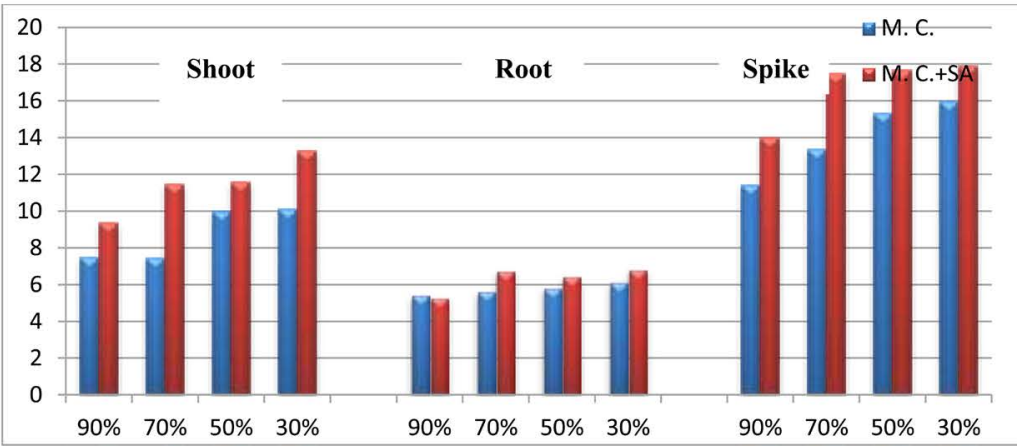

Figure 4. The response of Giza 123 (a), Giza 2000 (b), Giza 123 (c) and Giza 129 (d) barley genotypes to drought stress and interactive with SA treatments on osmotic pressure $\left(\mathrm{mOsmo} / \mathrm{H}_{2} \mathrm{O}\right)$ in shoot, root and spike of at the final fruiting stage.

and dry matter of shoot, root and spike. The percent of reduction in leaf area at $30 \%$ M. C. level was $81.8 \%, 60.7 \%, 54.9 \%$ and $53.3 \%$ in four tested barley genotypes respectively. The differences in the growth criteria among species and cultivars might be used as a suitable selection criterion for the drought tolerance of these species and genotype. The inhibitory effect of drought on growth parameters could be attributed to the osmotic effect of water stress [29]. Also, the 
reduction of yield may be ascribed to the harmful effect of soil moisture stress and nutrient balance disorder in root media [30], or reduced rate of new cell production may be make additional contribution to the inhibition of growth [31]. The reduction in growth criteria due to drought stress might be related to disturbance of water flow from root to shoot [32], decrease in water potential of cell sap [33], or inhibition of cell division [34]. Moreover, the percent of reduction in Chl. a, Chl. b and carotenoids was $80.3 \%, 98.9 \%, 67.4 \%, 87.6 \%, 58.3 \%$, $97.1 \%, 54.3 \%, 50 \%, 88.6 \%, 54.1 \%, 38.9 \%$ and $74.1 \%$ in four ranking barley genotypes. So lowering in green area of tested genotypes served in reduction in the efficiency of photosynthetic system which directly effected on carbohydrate production [35]. Actually, this indicated that Giza 123 was the superior in its drought tolerance and Giza 129 was the interior and both Giza 2000 and Giza 124 were the intermediated between them. This coincided with increasing in soluble sugar and soluble protein content of shoot, root and spike, shoot $\mathrm{Ca}^{++}, \mathrm{K}^{+}$ and $\mathrm{Mg}^{++}$in spike of Giza 123. In Giza 2000, this was related with a huge accumulation of soluble sugar in spike, soluble protein of three tested organs, shoot amino acids, $\mathrm{Ca}^{++}$and $\mathrm{Mg}^{++}$in spike. Whereas drought stress increased soluble sugar of spike, soluble protein in shoot, root and spike, $\mathrm{Ca}^{++}$and $\mathrm{Mg}^{++}$in root organ of Giza 124 while in Giza 129 the highest sensitive genotype decreasing M. C. increased soluble sugar of spike, soluble protein and amino acids in three tested organs, shoot $\mathrm{Ca}^{++}$, root $\mathrm{Mg}^{++}$was recorded i.e. each genotype try to overcome and facing drought stress. The previous observation was induced as a result of increasing OP in shoot, root and spike of four barley genotypes, the percent of increasing in osmotic pressure at 30\% moisture content was $132.6 \%$, $117.5 \%$, and $115.4 \%$ in Giza 123, in Giza 2000 it was $135.8 \%, 126.3 \%$ and $127.8 \%$, in Giza 124 was $134.4 \%, 117.6 \%$ and $129.3 \%$, finally in Giza 129 it was $135.2 \%, 113.0 \%$ and $135.1 \%$ compared with undroughted plants respectively. This mean that the medium percent of increasing in OP value was more or less similar in shoot of four barley genotypes was about $34.5 \%$ over the control plants $100 \%$ and also in root organ was about $18.6 \%$. However in spike this situation was different the most barley drought tolerant Giza 123 was the lower in percent of increasing OP value was $15.4 \%$ over the control value $100 \%$ and the most drought sensitive was the higher increasing percent value was $35.1 \%$ in Giza 129 genotype. It is interesting to note that the percent of increasing value in OP of Giza 2000 and Giza 124 was respectively intermediated $27.8 \%$ and $29.3 \%$ over the control plants [36]. Osakabe et al. (2017) [37] showed that cell growth caused by cell expansion is regulated primarily by turgor pressure, which is the physical force against the cell wall, and is maintained by osmotic regulation via osmotically active substances, such as potassium ions $\left(\mathrm{K}^{+}\right)$as in Giza 123 , sugars as in spike of four tested genotypes, protein as in Giza 123, Giza 2000 and Giza 129 and amino acids as in shoot of Giza 2000 and Giza 129 genotype. $\mathrm{K}^{+}$is an essential element in plant growth, and $\mathrm{K}^{+}$uptake and efflux affect plant productivity and control cell water potential and turgor in osmotic regulation. $\mathrm{K}^{+}$affects os- 
motic pressure in the root xylem (root pressure), which drives long-distance sap flow from roots to shoots [38]. During water deficit stress, osmotic stress sensing and signaling are pivotal to plant water status and lead to rapid changes in gene expression [39] [40]. Osmotic adjustment helps to maintain cell turgor, which can allow cell enlargement and plant growth during water stress; and it can allow stomata to remain at least partially open and $\mathrm{CO}_{2}$ assimilation to continue at water potentials that would be otherwise inhibitory [41] (Alves and Setter, 2004). Supported the previous view that drought stress is among the factors most limiting to plant productivity [35] [42] [43] [44] [45] [46]. Plants exposed to drought stress adapt their metabolism in order to cope with the changed environment. Survival under these stressful conditions depends on the plant's ability to perceive the stimulus, generate and transmit signals and instigate biochemical changes that adjust the metabolism accordingly [47] [48] [49] [50] [51]. One distinctive feature of most plants growing in stress environments is the accumulation of proline [52] [53] and it has been inferred that there may be a relationship between cellular proline level and cell turgidity via osmotic adjustment [54] [55] [56] [57] [58]. From our results it can be confirmed that root is more sensitive than shoot organ in four tested barley genotypes. This related with the higher accumulation of different metabolites as soluble sugar and proline content which the later reached 5-folds than shoot in Giza 123. In root of Giza 2000 soluble protein and proline which later also reached 3-folds compared with control. Whereas in root of Giza 124 a higher accumulation of soluble protein especially at higher drought stress (30\% M. C.) was recorded. In Giza 129 a higher accumulation of proline in root than in shoot, these observation was coincided with lower values in water content and OP in root compared with shoot in four tested cultivars. This position throw attention that root sensitivity was induced as a resulted of increase the previous chemical constituents to give chance in increasing $\mathrm{OP}$ and gain the requirement of water content and translocation from root to aerial portion for metabolism. Also root sensitivity may be due to, it was considered as the first site of plant in facing water deficit injury than other plant parts [56] [57] [58]. The strategies that plants use to defense drought position involve several mechanisms of stress tolerance, which vary according to the genotype [59] [60] [61]. Many genes involved in stress reactions reveal a complex network of responses required from the perception and recognition of the signals during stress to the final activation of certain genes [62] [63] [64]. Exogenously applications of SA helped to increase plant growth significantly in drought conditions [10] [47] [65] [66] [67] [68] [69]. Exogenously applications of SA strongly inhibited $\mathrm{Na}^{+}, \mathrm{K}^{+}$and $\mathrm{Cl}^{-}$and organic solute accumulations (GB and TSC) but stimulated N and RWC [69]. Najafian et al. (2009) [70] showed that SA treated plants had a higher shoot and root dry matter, electrolyte leakage, photosynthetic rates, mesophyll efficiency and water use efficiency in compared to control plants when exposed to salt stress. Transpiration rates and stomatal conductance were also significantly iesser in SA treated plants under saline stress 
conditions. Foliar application of SA $(1.0 \mu \mathrm{M})$ strengthened antioxidant defense system in drought-tolerant $Z$. mays cultivar to a great extent [71] [72]. Potential involvement of SA in the 76 identified proteins was reported in drought-exposed T. aestivum [14]. Theses identified proteins were advocated to perform major physiological processes such as photosynthesis, carbohydrate and protein metabolism, defense energy production, signal transduction, and toxin metabolism. Some of the recent studies have shown that SA played an important role by regulating many metabolic mechanisms. Marcińska et al. (2013) and Nazarli et al., (2014) [73] [74] showed that treatments plants with SA, MeJA and ABA were also effective in enhancing the antioxidant concentrations of proline and soluble sugars. The production of these antioxidants could have been part of a defense system against drought injury, reducing MDA and ELI and maintaining membrane stability. Therefore, this work try to throw attentions on mechanisms of drought tolerance of four barley genotypes and the potential role of SA on this strategy.

\section{Acknowledgements}

My greet loving Prof Dr. Hamdia for all member of my family (Father M. Abd El-Samad, mother Karema Kotob, Brother Ahmed and Naema sister) which encouragements.

\section{Conflicts of Interest}

The authors declare no conflicts of interest regarding the publication of this paper.

\section{References}

[1] Anjum, S.A., Xie, X., Wang, L., Saleem, M.F. and Wang, L. (2001) Morphologial, Physiological and Biochemical Responses of Plants to Drought Stress. African Journal of Agricultural Research, 6, 2026-2032.

http://www.academicjournals.org/article/article1380900919_Anjum\%2520et\%2520a l.pdf

[2] Khan, M.I.R. and Khan, N.A. (2013) Salicylic Acid and Jasmonates: Approaches in Abiotic Stress Tolerance. Journal of Plant Biochemistry and Biotechnology, 1, e113. https://www.omicsonline.org/open-access/salicylic-acid-and-jasmonates-approache s-in-abiotic-stress-tolerance-2329-9029.1000e113.pdf

[3] Muscolo, A. and Junker, A.A. (2015) Phenotypic and Metabolic Responses to Drought and Salinity of Four Contrasting Lentil Accessions. Journal of Experimental Botany, 66, 5467-5480. https://www.ncbi.nlm.nih.gov/pubmed/25969553 https://doi.org/10.1093/jxb/erv208

[4] Boyer, J.S. (2016) Plant Productivity and Environment. Science, 218, 443-448. http://science.sciencemag.org/content/218/4571/443/tab-article-info https://doi.org/10.1126/science.218.4571.443

[5] Miura, K. and Tada, Y. (2014) Regulation of Water, Salinity, and Cold Stress Responses by Salicylic Acid. Frontiers in Plant Science, 5, 4.

https://www.ncbi.nlm.nih.gov/pmc/articles/PMC3899523/ 
[6] Kang, G.Z., Li, G.Z., Liu, G.Q., Xu, W., Peng, X.Q., Wang, C.Y., Zhu, Y.J. and Guo, T.C. (2013) Exogenous Salicylic Acid Enhances Wheat Drought Tolerance by Influence on the Expression Ogenesrelated to Ascorbate-Gluathione Cycle. Biologia Plantarum, 57, 718-724. https://doi.org/10.1007/s10535-013-0335-Z

[7] Rivas, S. M. and Plasencia, V.J. (2011) Salicylic Acid beyond Defence: Its Role in Plant Growth and Development. Journal of Experimental Botany, 62, 3321-3338. https://www.ncbi.nlm.nih.gov/pubmed/21357767 https://doi.org/10.1093/jxb/err031

[8] Hara, M., Furukawa, J., Sato, A., Mizoguhi, T. and Miura, K. (2012) Abiotic Stress and Role of Salicylic Acid in Plants. In: Parvatiza, A. and Prasad, M.N.V., Eds., Biotic Stress Responses in Plants, Springer, New York, 235-251.

https://www.springer.com/gp/book/9781461406334

[9] Jayakannan, M., Bose, J., Babourina, O., Rengei, Z. and Shabala, S. (2013) Salicylic Acid Improves Salinity Tolerance in Arabidopsis by Restoring Membrane Potential and Preventing Salt-Induced $\mathrm{K}^{+}$Loss via a GORK Channel. Journal of Experimental Botany, 64, 2255-2268.

https://www.researchgate.net/journal/1460-2431_Journal_of_Experimental_Botany https://doi.org/10.1093/jxb/ert085

[10] Hovath, E., Pal, M., Szalai, G., Paldi, E. and Janda, T. (2007) Exogenous 4-Hydroxybenzoi Aid and Salicylic Acid Modulate the Effect of Short-Term Drought and Freezing Stress on Wheat Plants. Biologia Plantarum, 51, 480-487.

https://link.springer.com/article/10.1007/s10535-007-0101-1 https://doi.org/10.1007/s10535-007-0101-1

[11] Tuteja, N. and Sopory, S.K. (2008) Chemical Signaling under Abiotic Stress Environment in Plants. Plant Signaling \& Behavior, 3, 525-536. https://doi.org/10.4161/psb.3.8.6186

[12] Asensi-Fabado, M. and Munné-Bosch, S. (2011) The aba3-1 Mutant of Arabidopsis thaliana Withstands Moderate Doses of Salt Stress by Modulating Leaf Growth and Salicylic Acid Levels. Journal of Plant Growth Regulation, 30, 456-466.

https://www.researchgate.net/publication/251088548_The_aba3-1_Mutant_of_Arabido psis_thaliana_Withstands_Moderate_Doses_of_Salt_Stress_by_Modulating_Leaf_Gro wth_and_Salicylic_Acid_Levels

[13] Singh, B. and Usha, K. (2003) Salicylic Acid Induced Physiological and Biochemical Changes in Wheat Seedlings under Water Stress. Plant Growth Regulation, 39, 137-141. https://link.springer.com/article/10.1023/A:1022556103536

[14] Khan, M.R., Fatma, M., Per, T.S., Anjum, N.A. and Khan, N.A. (2015) Salicylic Acid-Induced Abiotic Stress Tolerance and Underlying Mechanisms in Plants. Frontiers in Plant Science, 6, 462. https://www.ncbi.nlm.nih.gov/pubmed/26175738

[15] Khan, N., Bano, A. and Zandi, P. (2018) Effect of Exogenously Applied Plant Growth Regulators in Combination with PGPR on the Physiology and Root Growth of Chickpea (Cicerarientum) and Their Role in Drought Tolerance. Journal of Plant Interactions, 13, 239-247. https://doi.org/10.1080/17429145.2018.1471527

[16] Brady, N.C. and Weil, R.R. (2002) Nature and Properties of Soils. 13th Edition, Pearson Education Incorporation, Upper Saddle River, NJ.

https://www.researchgate.net/publication/301200878_The_Nature_and_Properties_ of_Soils_15th_edition

[17] Tibbits, T.W. and Langhans, R.W. (1993) Controlled-Environment Studies. In: Hall, D.O., Scur, R.W., Lock, J.M., Bolhar-Nordenkampf, H.R., Leegoood, R.C. and Long, S.P., Eds., Photosynthesis and Production in a Changing Environment, Chapman and Hall, London, 65-78. 
[18] McKee, G.W. (1974) A Coefficient for Computing Leaf Area in Hybrid Corn. Agronomy Journal, 56, 240-241. https://doi.org/10.2134/agronj1964.00021962005600020038x

[19] Bonhomme, R., Varlet, M., Grancher, C. and Chartier, P. (1974) The Use of Hemispherical Photography for Determining Leaf Index of Young Crops. Photosynthetica, 8, 299-301. https://searchworks.stanford.edu/view/373886

[20] Norman, J. and Campbell G.S. (1994) Canopy Structure. In: Pearcy, R.W., Ehleringer, J., Moony, H.A. and Rundel, P.W., Eds., Plant Physiological Ecology, Chapman and Hall, London, 301-326.

[21] Metzner, H., Rau, H. and Senger, H. (1965) Untersuchungen zur Synchronisierbarkeit einzelner Pigmentmangel-Mutanten von Chlorella. Planta, 65, 186-194. https://doi.org/10.1007/BF00384998

[22] Fales, D.R. (1951) The Assimilation and Degradation of Carb. Plant Soil Hydratsteudies of Yeast Cells. Journal of Biological Chemistry, 193, 113-118. https://www.degruyter.com/view/j/bchm

[23] Lowry, O.H., Roserbrogh, N.J., Farr, L. and Ramadal, R.J. (1951) Protein Measurement with the Folin Phenol Reagent. Journal of Biological Chemistry, 193, 265-275. https://en.wikipedia.org/wiki/Journal_of_Biological_Chemistry

[24] Moore, S. and Stien, W. (1948) Photometric Ninhydrin Method for Use in the Chromatography of Amino Acids. Journal of Biological Chemistry, 176, 367-388. https://www.ncbi.nlm.nih.gov/pubmed/18886175

[25] Bates, L.W., Waldern, R.P. and Teare, I.D. (1973) Rapid Determination of Free Proline for Water Stress. Plant and Soil, 39, 205-207. https://www.plantstress.com/Methods/Proline\%20analysis.pdf

[26] Williams, V. and Twine, S. (1960) Flam Photometric Methods for Sodium, Potassium and Calcium. In: Paech, K., Tracey and M.V., Eds., Modern Methods of Plants Analysis, Springer-Verlag, Berlin. https://en.wikipedia.org/wiki/The_Williams_Brothers

[27] Shchwarzenbach, G. and Biedermann, W. (1948) Complexons X. Alkaline Earth Complexes of O,O-Dihydroxyazodyes. Helvetica Chimica Acta, 31, 678-687. https://www.google.com/search?q=Shchwarzenbach, + G.+and+Biedermann, + W.+(1 948):+Complexons + X.+Alkaline + earth + complexes + of $+\mathrm{O}, \mathrm{O}-$ dihydroxyazodyes. $+\mathrm{H}$ elv.Chim.Acta. $+31:+678-687 . \& \mathrm{tbm}=\mathrm{isch} \& \mathrm{tbo}=\mathrm{u} \&$ source $=$ univ\&sa $=\mathrm{X} \& v e d=2 \mathrm{ahUK}$ EwiKhM3ap7DdAhVM5IUKHUGkDI4Q7Al6BAgEEBM\&biw=1366\&bih=653

[28] Steel, R.G. and Torrie, J.H. (1960) Principles and Procedures of Statistics. McGrawHill Book Co., New York. http://59.80.44.48/garfield.library.upenn.edu/classics1977/A1977DU23500002.pdf

[29] Salter, M.G., Franklin, K.A. and Whitelam, G.C. (2003) Gating of the Rapid ShadeAvoidance Response by the Circadian Clock in Plants. Nature, 426, 680-683. https://www.ncbi.nlm.nih.gov/pubmed/14668869 https://doi.org/10.1038/nature02174

[30] Farooq, M., Wahid, A., Kobayashi, N., Fujita, D. and Basra, S.M.A. (2009) Plant Drought Stress: Effects, Mechanisms and Management. Agronomy for Sustainable Development, 29, 185-212. https://hal.archives-ouvertes.fr/hal-00886451/document

[31] Baek, D., Chun, H.J. and Jin, Y.D. (2016) A Role for Arabidopsis miR399f in Salt, Drought, and ABA Signaling. Molecules and Cells, 39, 111-118. https://www.ncbi.nlm.nih.gov/pmc/articles/PMC4757798/

[32] Woodruff, D.R. and Meinzer, F. (2013) Water Stress, Shoot Growth and Storage of Non-Structural Carbohydrates along a Tree Height Gradient in a Tall Conifer. Plant, 
Cell and Environment, 34, 1920-1930.

https://www.ncbi.nlm.nih.gov/pubmed/21722142

[33] Ribaut, J.M. and Pilet, P.E. (1991) Effect of Water Stress on Growth, Osmotic Potential and Abscisisc Acid Content of Maize Roots. Physiologia Plantarum, 81, 1399.

[34] Bracale, M.M., Levi, C., Savini, W., Dicorato, W. and Galli, M.G. (1997) Water Deficit in Pea Root Tips: Effect on the Cell Cycle and on the Production of DehydrinLike Proteins. Annals of Botany, 79, 593-600. https://academic.oup.com/aob/article/79/6/593/2587611

[35] Shaddad, M.A.K., El-Samad, M.H.A. and Mohamed, H.T. (2011) Interactive Effects of Drought Stress and Phytohormones or Polyamines on Growth and Yield of Two Maize (Zea maize L.) Genotypes. American Journal of Plant Sciences, 2, 790-807. https://file.scirp.org/pdf/AJPS20110600003_87819203.pdf

[36] Hamdia, M.A. (2016) The Potential Role of Osmotic Pressure to Exogenous Application of Phytohormones on Crop Plants Grown under Different Osmotic Stress. American Journal of Plant Sciences, 7, 937-948.

http://www.scirp.org/journal/PaperInformation.aspx?paperID=65969

[37] Osakabe, Y. and Osakabe, K. (2017) Chapter Six-Genome Editing to Improve Abiotic Stress Responses in Plants. In: Progress in Molecular Biology and Translational Science, Vol. 149, Elsevier, Amsterdam, 99-109.

https://www.researchgate.net/publication/316703565_Genome_Editing_to_Improv e_Abiotic_Stress_Responses_in_Plants https://doi.org/10.1016/bs.pmbts.2017.03.007

[38] Lebaudy, A., Véry, A.A. and Sentenac, H. (2007) $\mathrm{K}^{+}$Channel Activity in Plants: Genes, Regulations and Functions. FEBS Letters, 58, 2357-2366.

https://www.researchgate.net/publication/6404735_K_channel_activity_in_plants_ Genes_regulations_and_functions

[39] Yamaguchi, S.K. and Shinozaki, K. (2006) Transcriptional Regulatory Networks in Cellular Responses and Tolerance to Dehydration and Cold Stresses. Annual Review of Plant Biology, 57, 781-803. https://www.ncbi.nlm.nih.gov/pubmed/16669782

[40] Hajihasshemi, S. and Sofo, A. (2018) The Effect of Polyethylene Glycol-Induced Drought Stress on Photosynthesis, Carbohydrates and Cell Membrane in Stevia rebaudiana Grown in Green House. Acta Physiologiae Plantarum, 40, 142. https://doi.org/10.1007/s11738-018-2722-8

[41] Alves, A.A.G. and Setter, T.L. (2004) Abscisic Acid Accumulation and Osmotic Adjustment in Cassava under Water Deficit. Environmental and Experimental Botany, 51, 259-279.

https://www.infona.pl/resource/bwmeta1.element.elsevier-3bb926c8-a890-3493-a73 5-b135d10a490f

[42] Shi, H., Quintero, F.J., Pardo, J.M. and Zhu. J.K. (2002) The Putative Plasma Membrane $\mathrm{Na}^{+} / \mathrm{H}^{+}$Antiporter SOS1 Controls Long Distance $\mathrm{Na}^{+}$Transport in Plants. The Plant Cell, 14, 465-477. https://www.ncbi.nlm.nih.gov/pubmed/11884687

[43] Reddy, A.R., Chaitany, K.V. and Vivkanadau, M. (2004) Drought-Induced Responses of Photosynthesis and Antioxidant Metabolism in Higher Plants. Journal of Plant Physiology, 161, 1189-1202. https://www.ncbi.nlm.nih.gov/pubmed/15602811 https://doi.org/10.1016/j.jplph.2004.01.013

[44] Hamdia, M.A., El-Samad, M.A.K. and Mohammed, H.T. (2013) Drought Tolerance of Some Zea mays Genotypes at Early Growth Stage. Academia Journal of Biotechnology, 1, 121-126. 
https://academiapublishing.org/journals/ajb/pdf/2013/Oct/Shaddad\%20et\%20al.pdf

[45] Osakabe, Y., Arainaga, N., Umezawa, T., Katsura, S., Nagamahi, K. and Tanaka, H. (2013) Osmotic Stress Responses and Plant Growth Controllesd by Potassium Transporters in Arabidopsis. The Plant Cell, 25, 609-624.

https://www.ncbi.nlm.nih.gov/pubmed/23396830

https://doi.org/10.1105/tpc.112.105700

[46] Osakabe, Y., Osakabe, K. and Tran, L.P. (2014) Response of Plants to Water Stress. Frontiers in Plant Science, 5, 86.

https://www.ncbi.nlm.nih.gov/pmc/articles/PMC3952189 https://doi.org/10.3389/fpls.2014.00086

[47] Hussain, M., Malik, M.A., Farooq, M., Ashraf, Y. and Heema, M.A. (2008) Improving Drought Toleracne by Exogenous Application of Glycinebetaine and Salicylic Acid in Sunflower. Journal of Agronomy and Crop Science, 194, 193-199. https://doi.org/10.1111/j.1439-037X.2008.00305.x

[48] Hussain, K., Nawaz, K., Majeed, A., Yas, U., Lin, F., Ali, K. and Nisar, M.F. (2011) Role of Exogenous Salicylic Acid Applications for Salt Tolerance in Violet. Sarhad Journal of Agriculture, 27, 171-175.

https://www.aup.edu.pk/sj_pdf/3-ROLE\%20OF\%20EXOGENOUS\%20SALICYLIC \%20ACID\%20APPLICATIONS.pdf

[49] Cazares, B.X., Ramirez-Ortega, F.A., Elenes, L.F. and Medrano, R.R. (2010) Drought Tolerance in Crop Plants. American Journal of Plant Physiology, 5, 241-256. https://scialert.net/fulltextmobile/?doi=ajpp.2010.241.256

[50] Hamdia, M., El-Samad, A. (2016) The Physiological Role of Proline and Sodium as Osmotic Stress Signal Components of Some Crop Plants. Triticeae Genomics and Genetics, 3, 1-9.

[51] Hamdia, M., Abd, E.S., Mostafa, D., Abd, E.H. (2017) The Combined Action Strategy of Two Stresses, Salinity and $\mathrm{Cu}^{++}$on Growth, Metabolites Andprotein Pattern of Wheat Plant. American Journal of Plant Sciences, 8, 625-643.

http://www.scirp.org/(S(i43dyn45teexjx455qlt3d2q))/journal/PaperInformation.asp $\mathrm{x}$ ?PaperID=74486 https://doi.org/10.4236/ajps.2017.83043

[52] Kumar, B., Pandey, D.M., Goswami, C.L. and Jain, S. (2001) Growth Regulators on Photosynthesis, Transpiration and Related Parameters in Water Stressed Cotton. Biologia Plantarum, 44, 475-478. https:/link.springer.com/article/10.1023/A:1012408624665

[53] Jaarsma, R., de Vries, R.S.M. and de Boer, A.H. (2013) Effect of Salt Stress on Growth, $\mathrm{Na}^{+}$Accumulation and Proline Metabolism in Potato (Solanum tuberosum) Cultivars. PLoS ONE, 2, 9-14. https://doi.org/10.1371/journal.pone.0060183

[54] Hayashi, F., Ichino, T. and Osanai, M. and Wada, K., (2000) Oscillation and Regulation of Proline Content by P5CS and ProDH Gene Expressions in the Light/Dark Cycles in Arabidopsis thaliana L. Plant and Cell Physiology, 4, 1096-1101. https://academic.oup.com/pcp/article/41/10/1096/1859415 https://doi.org/10.1093/pcp/pcd036

[55] Kumara, S.G.A., Reddy, A.M. and Sudhakar, C. (2003) NaCl Effects on Proline Metabolism in Two High Yielding Genotypes of Mulberry (Morus alba L.) with Contrasting Salt Tolerance. Plant Science, 165, 1245-1251.

https://www.researchgate.net/publication/325203894_Turgor_Maintenance_by_Os motic_Adjustment_-_40_years_of_progress

https://doi.org/10.1016/S0168-9452(03)00332-7 
[56] Hamdia, M. Abd, E.S. and Barakat, N. (2013) The Physiological Mechanisms of Calcium Chloride Application on Broad Bean Plants Grown under Salinity Stress. Journal of Ecology and the Natural Environment, 5, 371-377. https://www.academicjournals.org/journal/JENE/article-full-text-pdf/D6A346642140 https://doi.org/10.5897/JENE10.089

[57] Nazar, R., Umar, S., Khan, N.A. and Sareer, O. (2015) Salicyic Acid Supplementation Improves Photosynthesis and Growth in Mustard through Changes in Proline Acculution and Ethylene Formation under Drought Stress. South African Journal of Botany, 89, 84-94. https://www.rsearhgate.net/publicaion/273527989

[58] Man, D., Bao, Y.X., Han, L.B and Zhang, X. (2017) Drought Tolerance Associated with Proline and Hormone Metabolism in Two Tall Fescue Cultivars. HortScience, 46, 1027-1032. https://www.researhgate.net/pubication/286404598

[59] Chaves, M.M., Flexas, J. and Pinheiro, C. (2009) Photosynthesis under Drought and Salt Stress: Regulation Mechanisms from Whole Plant to Cell. Annals of Botany, 103, 551-560. https://www.ncbi.nlm.nih.gov/pmc/articles/PMC2707345/

[60] Mattos-Moreira, L.A., Farreira, C.F., Amorim, E.P., Pirovani, C.P., Andrade, E.M., Filho, M.A. and da silva, I.C. (2018) Differentially Expressed Proteins Associated with Drought Tolerance in Bananas (Musa spp.). Acta Physiologiae Plantarum, 40, 60. https://doi.org/10.1007/s11738-018-2638-3

[61] Bray, E.A. (2009) Plant Responses to Water Deficit. Trends in Plant Science, 2, 48-54.

[62] Shinozaki, K., Yamaguchi-Shinozaki, K. (2000) Molecular Responses to Dehydration and Low Temperature: Differences and Cross-Talk between Two Stress Signaling Pathways. Current Opinion in Plant Biology, 3, 217-223. https://www.ncbi.nlm.nih.gov/pubmed/10837265

[63] Kacperska, A. (2004) Sensor Types in Signal Transduction Pathways in Plant Cells Responding to Abiotic Stressors: Do They Depend on Stress Intensity? Physiologia Plantarum, 122, 159-168.

[64] Seki, M., Umezawa, T., Urano, K. and Shinozaki, K. (2007) Regulatory Metabolic Networks in Drought Stress Responses. Current Opinion in Plant Biology, 10, 296-302. https://www.ncbi.nlm.nih.gov/pubmed/17468040

[65] Senaratna, T., Touhell, D., Bunn, E. and Dixon, K. (2000) Acetyl Salicylic Acid (Aspirin) and Salicylic Acid Induce Multiple Stress Tolerance in Bean and Tomato Plants. Plant Growth Regulation, 30, 157-161. https://ink.springer.com/article/10.1023/A:1006386800974 https://doi.org/10.1023/A:1006386800974

[66] Aroca, R., Porcel, R. and Ruiz, L.M. (2012) Regulation of Water Uptake under Abiotic Stress Conditions. Journal of Experimental Botany, 63, 43-57.

https://www.ncbi.nlm.nih.gov/pubmed/21914658 https://doi.org/10.1093/jxb/err266

[67] Fayes, K.A. and Bazaid, S.A. (2014) Improving Drought and Salinity Tolerance in Barley by Application of Salicylic Acid and Potassium Nitrate. Journal of Saudi Society of Agricultural Sciences, 13, 45-55. https://doi.org/10.1016/j.jssas.2013.01.001

[68] Iseki, K., Takahashi, Y., Muto, C., Naito, K. and Tomooka, N. (2018) Diversity of Drought Tolerance in Genus Vigna. Frontiers in Plant Science, 9, 729.

https://europepmc.org/abstract/pmc/pmc6014140

[69] Saruhan, N., Saglam, A. and Kadioglu, A. (2012) Salicylic Acid Pretreatment Induces Drought Tolerance and Delays Leaf Rolling by Inducing Antioxidant Systems in Maize Genotypes. Acta Physiologiae Plantarum, 34, 97-106. 
https://www.researchgate.net/publication/251402725_Salicylic_acid_pretreatment_ind uces_drought_tolerance_and_delays_leaf_rolling_by_inducing_antioxidant_systems_i n_maize_genotypes https://doi.org/10.1007/s11738-011-0808-7

[70] Najafian, S., Khoshkhu, M., Tavallali, V. and Saharkhiz, M.J. (2009) Effect of Salicylic Acid and Salinity in Thyme (Rosmarinus officinalis L.): Investigation on Changes in Gas Exchange, Water Relations, and Membrane Stabilization. Advances in Environmental Biology, 3, 322-328.

http://www.aensiweb.com/old/aeb/2009/322-328.pdf

[71] Kang, G., Li, G. and Guo, T. (2014) Molecular Mechanism of Salicylic Acid-Induced Abiotic Stress Tolerance in Higher Plants. Acta Physiologiae Plantarum, 36, 2287 2297.

[72] Pál, M., Kovács, V., Szalai, G., Soós, V., Ma, X. and Liu, H. (2014) Salicylic Acid and Abiotic Stress Responses in Rice. Journal of Agronomy and Crop Science, 200, 1-11. https://doi.org/10.1111/jac.12037

[73] Marcińska, I., Czyczyło-Mysza, E.S., Grzesiak, M.T., Janowiak, F., Filek, M., Dziurka, M., Dziurka, K., Waligórski, K.P., Cyganek, K. and Grzesiak, S. (2013) Alleviation of Osmotic Stress Effects by Exogenous Application of Salicylic or Abscisic Acid on Wheat Seedlings. International of Molecular Science, 14, 13171-13193. https://www.ncbi.nlm.nih.gov/pubmed/23803653 https://doi.org/10.3390/ijms140713171

[74] Nazarli, H., Ahmadi, A. and Hadian, J. (2014) Salicylic Acid and Methyl Jasmonate Enhance Drought Tolerance in Chamomile Plants. Journal of Herbmed Pharmacology, 3, 87-92. http://herbmedpharmacol.com/Abstract/JHP_20150527162528

\section{Abbreviations}

Salicylic acid, SA

Moisture content, M. C. 